\title{
Clotting Dysfunction in Sepsis: A Role for ROS and Potential for Therapeutic Intervention
}

\author{
Maria Elisa Lopes-Pires ${ }^{1, * \mathbb{D}}$, Jéssica Oliveira Frade-Guanaes ${ }^{2}$ and Gregory J. Quinlan ${ }^{1}$ \\ 1 National Heart and Lung Institute, Faculty of Medicine, Imperial College London, London W12 0NN, UK; \\ g.quinlan@imperial.ac.uk \\ 2 Adventist University of Sao Paulo, Engenheiro Coelho, Sao Paulo 05858-001, Brazil; \\ jessica.guanaes@unasp.edu.br \\ * Correspondence: m.lopes-pires@imperial.ac.uk
}

check for updates

Citation: Lopes-Pires, M.E.; Frade-Guanaes, J.O.; Quinlan, G.J. Clotting Dysfunction in Sepsis: A Role for ROS and Potential for Therapeutic Intervention. Antioxidants 2022, 11, 88. https:// doi.org/10.3390/antiox11010088

Academic Editor: Giordano Pula

Received: 8 December 2021

Accepted: 27 December 2021

Published: 30 December 2021

Publisher's Note: MDPI stays neutral with regard to jurisdictional claims in published maps and institutional affiliations.

Copyright: (c) 2021 by the authors. Licensee MDPI, Basel, Switzerland. This article is an open access article distributed under the terms and conditions of the Creative Commons Attribution (CC BY) license (https:// creativecommons.org/licenses/by/ $4.0 /)$.

\begin{abstract}
Sepsis is regarded as one of the main causes of death among the critically ill. Pathogen infection results in a host-mediated pro-inflammatory response to fight infection; as part of this response, significant endogenous reactive oxygen (ROS) and nitrogen species (RNS) production occurs, instigated by a variety of sources, including activated inflammatory cells, such as neutrophils, platelets, and cells from the vascular endothelium. Inflammation can become an inappropriate self-sustaining and expansive process, resulting in sepsis. Patients with sepsis often exhibit loss of aspects of normal vascular homeostatic control, resulting in abnormal coagulation events and the development of disseminated intravascular coagulation. Diagnosis and treatment of sepsis remain a significant challenge for healthcare providers globally. Targeting the drivers of excessive oxidative/nitrosative stress using antioxidant treatments might be a therapeutic option. This review focuses on the association between excessive oxidative/nitrosative stress, a common feature in sepsis, and loss of homeostatic control at the level of the vasculature. The literature relating to potential antioxidants is also described.
\end{abstract}

Keywords: sepsis; oxidative stress; nitric oxide; netosis; platelets; clotting dysfunction; vascular endothelium dysfunction

\section{Introduction}

Sepsis is a life-threatening condition that affects 30 million people worldwide per year and is considered one of the main causes of death amongst critically ill patients. Seen in context, sepsis-related mortality from 2009 to 2019 averaged 33.7\% in North America, 32.5\% in Europe, and 26.4\% in Australia [1]. In the United Kingdom, around 250,000 cases and 44,000 deaths from sepsis are reported every year [2]. In the United States, similarly high rates of sepsis diagnosis are reported annually, at some 1.7 million cases, with mortality rates in the region of 270,000 [3]. Specialist treatment for patients with sepsis often requires intensive care support to maintain failing organs systems, including the lungs, heart, and kidneys; such treatments can be complex and may require an extended length of hospital stay, all of which places a considerable fiscal burden on healthcare providers. In the United Kingdom, around two-thirds of patients with sepsis are treated in intensive care units (ICUs), with an annual estimated cost at $£ 15.6$ billion [4]. This represents a significant component of annual healthcare budgets; moreover, the need for further support for recovering patients as provided by primary care providers places an even greater burden budget. Again, for example, in 2011, U.S. hospitals spent \$24 billion treating patients with sepsis, representing $13 \%$ of total health care costs (reviewed by [5]).

Defining criteria for sepsis and associated syndromes have evolved over the years; the current definition describes sepsis as an uncontrolled host-mediated response to infection and life-threatening organ dysfunction. Any patient is diagnosed with sepsis when they attain a score of 2 by sequential organ failure assessment (SOFA). SOFA comprises a 
scoring system based around the functionality of respiratory, hepatic, cardiovascular, central nervous and renal systems, and platelet count $[6,7]$.

In response to pathogen infection, a protective pro-inflammatory response is initiated, but this can become deleterious and of extended duration, leading to sepsis, and over activation of the inflammatory system results in the production of reactive oxygen (ROS) and nitrogen species (RNS) to the extent that endogenous antioxidant protection becomes overwhelmed. The consequences of this are diverse in nature, including impacts on redoxbased cell signalling systems; direct damage to biomolecules; and, perversely, the potential for immunosuppression. A common component of severe sepsis is endothelial damage and the triggering of the coagulation system, which can progress to DIC, which is marked by macro and microvascular thrombosis and hemorrhage and is a leading cause of organ damage in sepsis [8]. This review aims to explore the potential role for ROS and RNS as initiators for adverse clotting and bleeding events in sepsis. Efforts to target these processes using antioxidant therapies will also be discussed.

\section{Disseminated Intravascular Coagulation in Sepsis}

To maintain homeostatic control of blood flow through the circulation, it is essential that the processes of platelet plug formation and fibrinolysis are tightly regulated. If coagulation or anticoagulation mechanisms become dysfunctional, loss of homeostatic control can result in pathologies such as DIC, which is commonly encountered in patients with sepsis. DIC is a coagulopathy that occurs as a result of extensive and inappropriate activation of the coagulation system. Persistent coagulation results in thrombotic occlusion of small- and medium-sized blood vessels of the circulation via the establishment of microthrombi owing to fibrin formation (reviewed by [9]). Additionally, cessation of fibrinolysis, the mechanism responsible for lyzing the clot generated by activation of hemostatic pathways, contributes to DIC development in sepsis (reviewed by [10]). It has been reported that the levels of plasminogen activator inhibitor-1 (PAI-1), the protein responsible for assuring the clot preservation, is elevated in sepsis and is correlated with cytokines' releases and poor patients' outcome [11-13]. Another study, with the plasma of diabetics patients, demonstrated a strong correlation between the rise in oxidation markers (oxidized low-density lipoprotein and nitrotyrosine) and the impairment of the fibrinolysis process [14] (see Figure 1).

As such, compromised blood flow to key organs can result in multiple organ failure (MOF) and mortality, although other hemodynamic and metabolic disorders can similarly disrupt blood flow with similar outcomes $[15,16]$. In this regard, clinical guidelines relating to DIC state that, for better treatment and improved patient outcome, it is important to differentiate specific clinic phenotypes of disease type, including (1) increased fibrinolysis, such as would be associated with leukemia, trauma, and aortic or obstetric diseases; (2) suppressed fibrinolysis, associated with organ failure and septicemia; or (3) balanced fibrinolysis, such as would be observed with solid cancers $[17,18]$. Up to $40 \%$ of patients with sepsis present with or develop DIC [5,19-21]. During episodes of DIC, both bleeding and clotting events occur concurrently, which poses considerable issues regarding therapeutic approaches given the need to try and balance these opposing events [22]. 


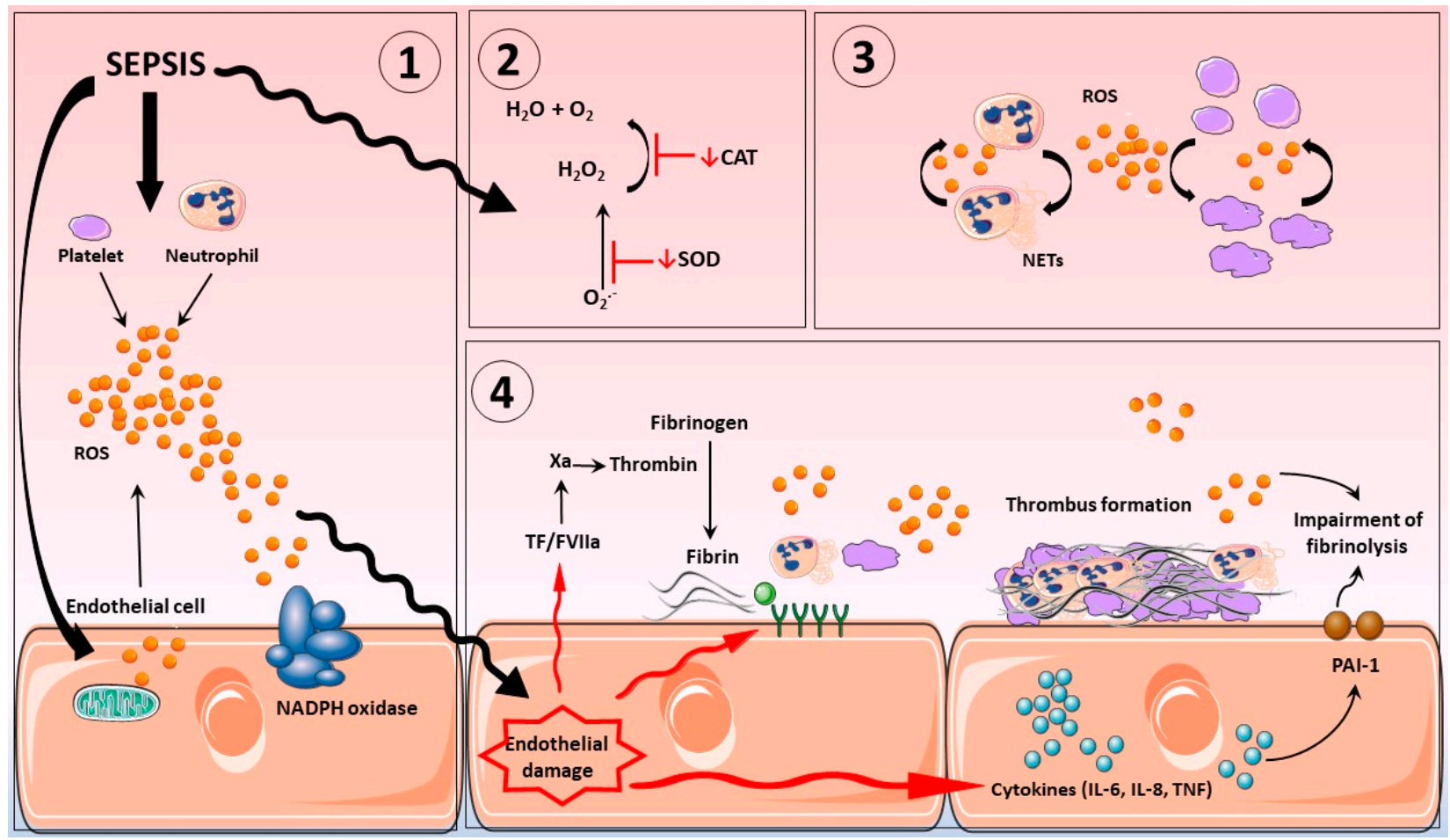

Figure 1. Sepsis induces oxidative stress and disseminates intravascular coagulation. (1). Sepsis induces ROS release by platelets, neutrophils, and endothelial cells. The majority of excessive ROS production is generated by mitochondria and NADPH oxidase present in endothelial cells, platelet, and neutrophil. (2). The overproduction of ROS results in depletion of endogenous antioxidant systems, including but not limited to SOD and catalase. (3). ROS release from activated inflammatory cells such as neutrophils and platelets further propagate inflammatory responses including further ROS production, processes that are self-sustaining and ever expanding. (4). Damage to the vascular endothelium augments inflammatory cytokine production via ROS-mediated stress responses and activates the coagulation system and expression of adhesion molecules, all of which results in elevation of fibrin deposition; impairment of fibrinolysis; and, consequently, thrombus formation. ROS: reactive oxygen species. CAT: catalase. SOD: superoxide dismutase. TF: tissue factor. NETs: neutrophil extracellular traps.

A variety of clinical scoring methods have been developed with the intent to help physicians estimate the severity of disease in sepsis; however, such systems lack precision as definitive symptoms and clear diagnosis criteria are not obvious in many patients $[16,23]$ Currently, the most widely used DIC criteria scores are those as set out by The International Society of Thrombosis and Haemostasis (ISTH) and the Japanese Association for Acute Medicine (JAAM) [16].

The development of DIC in sepsis is thought to involve crosstalk between the inflammatory system activation and the overstimulation of coagulation and, more specifically, a deficient natural anticoagulant system, which leads to platelet activation and neutrophil extracellular trap formation, followed by fibrin deposition [24-26].

The disproportionate host inflammatory response to pathogens during sepsis results in dysfunction and damage to the vascular endothelium, largely due to the effects of a cytokine storm, with inflammatory cytokines such as tumor necrosis factor a (TNF $\alpha)$, interleukins $1 \mathrm{~b}$ and 6 (IL-1b and IL-6), and interferon-gamma (IFNg) being implicated [27]. IL-6 is reported to play a central role in the activation of coagulation by tissue factor (TF) [16]. TF is a transmembrane glycoprotein able to activate the coagulation cascade when it is exposed to blood, under which circumstances the formation of a complex with FVII/FVIIa can ensue (reviewed by [28]), a frequent occurrence during endotoxemia [29]. Established beliefs indicated that TF was present and active only on general cell membranes; 
however, recent evidence has demonstrated the presence of TF on the surface of extracellular vesicles and microparticles (MPs), derived from platelets, leukocyte, and endothelial cells in patients with sepsis and DIC [30]. In addition to TF releasing, MPs also induce exposure of phosphatidylserine (PS), a phospholipid found on the surface of activated platelets that binds to an array of intrinsic and extrinsic factors to generate thrombin, a fundamental event of blood coagulation [31]. In addition, PS is associated with a significant increase in IL-6 and platelet activity, which correlates with the progression of endothelial damage and leukocyte activation [32,33].

While overexpression of pro-inflammatory cytokines enhances the activation of clotting cascades in sepsis, there is also good evidence to indicate associated impairment of pathways for essential natural anticoagulant activity, such as the antithrombin system, which is an important inhibitor of thrombin formation and FXa activation; the protein C system including protein $\mathrm{S}$, which is an essential co-factor for the activity of protein $\mathrm{C}$; and for thrombomodulin expression on endothelial cells (reviewed by [28]). Levels of protein C and antithrombin are markedly reduced in patients with sepsis with DIC [19]. Moreover, higher levels of protein $C$ are associated with better patient outcomes in general, and as such may offer use as a both a clinical biomarker and a therapeutic target [34].

\section{Vascular Haemostasis in Sepsis}

\subsection{Endothelium}

The glycocalyx is a complex structure that consists of proteoglycans, glycoproteins, and glycosaminoglycan chains found on the surface of endothelial cells, and it plays a critical role in the regulation of vascular permeability; for a full description, see [35]. Sepsis-induced endothelial dysfunction including glycocalyx shedding results in increased leucocyte adhesion to endothelial cells, thereby exacerbating tissue damage [36]. Injury to the glycocalyx is known to be accentuated by increased levels of inflammatory molecules such as IL-1b. Diabetes likely further increases the associated risk; to this end, a recent study undertaken in mice demonstrated that diabetes limits glycocalyx synthesis, which is further damaged by endotoxemia [37]. Importantly, patients with diabetes have higher hospital admission rates when compared with non-diabetics [38].

It is increasingly recognized that disruption of vascular endothelium functionality is an important contributing factor to the onset of the progression of sepsis, including coagulation disorders, where TF and other procoagulant factors are known to be increased by high levels of inflammatory mediators. As such, studies have shown significant associations between markers of endothelial dysfunction and mortality, including increases in expression of endocan, Ang-2 and HMGB-1, and decreasing levels of protein C with TF levels [34].

Given the emerging understanding of endothelial dysfunction in sepsis, therapeutic approaches designed to protect the endothelium and glycocalyx are the subject of ongoing investigation. Indeed, a recent study has demonstrated in an animal rodent model of sepsis that recombinant antithrombin was able to protect the endothelial glycocalyx from injury, thus maintaining vascular integrity. Moreover, this approach was shown to decrease levels of syndecan-1, which is an important biomarker of glycocalyx damage [39]. Moreover, outcomes of ProCESS, a randomized study for resuscitation strategies undertaken in 1341 patients, found associations for the expression of endothelial biomarkers of permeability with mortality in sepsis, including at baseline and $24 \mathrm{~h}$ mortality. A decrease in expression of VEGF was observed, whereas there was an increase in the expression of angiopoietin-2, tissue plasminogen activator, thrombomodulin, and von Willebrand factor [40], leading to an increase in thrombus and associated with the increase in mortality in sepsis.

\subsection{Platelets}

Platelets are anucleate blood cells derived from megakaryocytes that are able to release cytokines, and that interact with leukocytes and endothelial cells, performing fundamental roles in both vascular homeostasis and coagulation. Platelet activation represents an im- 
portant host response to infection for both innate and adaptive immunity [41]. In sepsis, platelets are implicated in coagulation dysfunction, through activation of pro-inflammatory mediators such as platelet activating factor and increasing fibrin formation via the expression of procoagulant molecules, including P-selectin [28,42,43]. However, decreased platelet counts (thrombocytopenia) may act as a predictor of mortality for patients with sepsis/septic shock and DIC [44]. The reasons for persistent thrombocytopenia in sepsis are not fully understood, but some theories suggest that this may be due to reduced platelet production, enhanced turnover, or spontaneous aggregation of platelets and enhanced platelet consumption through the formation of microthrombi. Although persistent platelet activation is most often related to septicemia, a few studies have shown that platelet aggregation is decreased in experimental sepsis [45], possibly signalled via the TNF pathway [46]. Moreover, the reduction in platelet aggregation seen in patients with sepsis is more pronounced depending on the severity sepsis, stage of disease, and the presence of DIC [47].

\subsection{Neutrophils}

Neutrophils are white blood cells that play a critical role in the immune response (reviewed by [48]) as well as in sepsis, which is associated with an excessive activation of neutrophils. Indeed, such neutrophil overstimulation is understood to be a key contributor to manifestations of sepsis and associated syndromes. In addition to the production of oxidants including hypochlorous acid (HOCL), hydrogen peroxide $\left(\mathrm{H}_{2} \mathrm{O}_{2}\right)$ and superoxide $\left(\mathrm{O}_{2}{ }^{\bullet-}\right)$, proteases, and chemokines, activated neutrophils are also capable of undergoing a process named netosis. The release of neutrophil extracellular traps (NETs) during netosis occurs when nuclear DNA decondenses to release web-like structures of linear DNA from the cell that are interlaced with histones, myeloperoxidase, and other antimicrobial peptides such as elastase [49-51]. NETs are able to trap and kill microorganisms owing to the activity of associated antimicrobial proteins, and they also limit parasite dissemination [52]. However, unwanted collateral effects linked to netosis have also been described, including the induction of tissue injury mediated by extracellular histones and granular proteins [53,54]. Moreover, some substances, such as elastase and myeloperoxidase, released by NETs are considered to be damage-associated molecular patterns (DAMPs) and can cause tissue injury through activation of toll-like receptors on endothelial cells, leading to dysfunction [55-57]; additionally, extracellular MPO is still capable of forming the damaging oxidant HOCL. Interestingly, it has been shown that the inhibition of neutrophil elastase can prevent NETs' formation and reduces septic shock in animal models, and thus may offer a therapeutic target for septicemia [58].

Some recent literature has demonstrated an association with the severity of sepsis and levels of NETs' formation. In this regard, higher levels of NETs' production correlated with the worsening and severity of sepsis and organ failure in humans; moreover, NETs' formation during the initial stages of sepsis was also positively correlated with levels of key inflammatory cytokines IL-8, IFN-gamma, and TNF $\alpha$ [59]. Furthermore, inflammatory modulation by NETs was reported lead to severe damage in the liver, spleen, and kidneys in a murine model, processes that were abrogated by the use therapeutic of anti-citrullinated protein antibody, a NET formation inhibitor $[57,60,61]$. Other modulators released during the acute inflammatory response have also been linked to the induction of NETosis. For example, cold-inducible RNA-binding protein (CIRP), which is a DAMP, is known to be associated with organ injury and increased mortality in sepsis, and has recently been shown to enhance NETosis in the mice lungs during sepsis in an animal model induced by a cecal ligation and puncture (CLP) model [62]. Previous studies have also demonstrated that some antibiotics such as fluoroquinolones, macrolides, and a few b-lactams are capable of modulating the formation of NETs and, as such, may offer a protective role in early sepsis, this being ascribed to an immunomodulatory function possibly owing to downregulation of the PKC-Akt-mTOR pathway [50]. 
In addition, given the context of this review, NETs' release is further linked to the evolution of DIC via the reduction in the levels of antithrombin and, as such, may provide a possible therapeutic target to treat DIC [58,63].

Importantly, the DNA molecule contains a polyphosphate backbone and is a known intracellular storage polymer of phosphate. Persistence of NETs is normally regulated by plasma DNAase 1 activity; there are nevertheless circumstances when such control is lost or overwhelmed, and net formation predominates [64]. DNA provides a negatively charged surface for the autocatalytic activation of Factor XII and the intrinsic pathway of coagulation, leading to increased thrombin generation and risk of thrombosis. Moreover, histones released with DNA are potent platelet activators, causing platelet degranulation and release of polyphosphate (PolyP). PolyP has been shown to be a highly potent activator of the contact pathway in vitro and in vivo $[65,66]$, binding with high affinity to several of its protein components. Therefore, targeted inhibition of the Factor XII pathway may offer a therapeutic option in sepsis.

\section{Oxidative and Nitrosative Stress}

Reactive oxygen species (ROS) are chemical species encompassing free radicals and related oxygen containing species. The most encountered inorganic ROS include the following: the superoxide radical anion $\left(\mathrm{O}_{2}{ }^{\bullet-}\right)$, the hydroxyl radical $\left({ }^{\bullet} \mathrm{OH}\right)$, hydrogen peroxide $\left(\mathrm{H}_{2} \mathrm{O}_{2}\right)$, and hypochlorous acid ( $\mathrm{HOCl}$ ) [67-69]. Most ROS production is purposeful, allowing for utilizations of oxygen for aerobic metabolism and biosynthesis. These processes are highly regulated to limit any adverse consequences related to the inappropriate activation of oxygen to more reactive forms. Should this control be undermined or lost, excessive ROS production can affect redox-regulated cell-signalling responses, leading to aberrant stress responses, as seen in sepsis. To this end, over production of $\mathrm{O}_{2}^{\bullet-}$ and $\mathrm{H}_{2} \mathrm{O}_{2}$, both key signalling species, can lead to redox-regulated pro-inflammatory transcription factor over activation as well as significant and inappropriate pro-inflammatory responses. The production of directly damaging $\mathrm{ROS}$ including $\bullet \mathrm{OH}$ and $\mathrm{HOCl}$ can also result in damage and dysfunction to an array of biomolecules, including lipids, proteins, and nucleic acids, as well as the production of toxic end-products such as aldehydes and protein carbonyls. Moreover, interactions between relatively innocuous species such as $\mathrm{O}_{2}{ }^{\bullet-}$ and nitric oxide (NO) in equimolar proportions result in the production of peroxynitrite $\left(\mathrm{ONOO}^{-}\right)$, which, although not a free radical, is nevertheless a very aggressive species capable of inflicting damage similar to that ascribed to ${ }^{\bullet} \mathrm{OH}$. Furthermore, $\mathrm{ONOO}^{-}$is capable of reacting with proteins and peptides, thereby causing functional changes; modifications include s-nitrosylation, glutathionylation, and tyrosine nitration. $\mathrm{NO}$ and $\mathrm{ONOO}^{-}$are described as reactive nitrogen species (RNS); other RNS include nitroxyl (HNO), nitrosonium cation $\left(\mathrm{NO}^{+}\right)$, S-nitrosothiols ( $\left.\mathrm{RSNOs}\right), \mathrm{NO}_{2}^{-}$(nitrite), and dinitrosyl iron complexes, excluding $\mathrm{NO}_{3}[70,71]$. Under normal conditions, endothelial cells generate $\mathrm{NO}$ through eNOS, influencing cGMP levels and relaxing vascular smooth muscle, thereby promoting the vessel dilation. NO is also a known inhibitor of platelet activity through the sGC-cGMPPKG pathway, following different mechanisms: (i) PKG reduces intraplatelet $\mathrm{Ca}^{2+}$ levels inhibiting platelet shape change and, consequently, inhibiting the release of mediators involved in platelet aggregation; (ii) PKG promotes the phosphorylation of $\mathrm{TXA}_{2}$ receptor, suppressing the effects of the platelet agonist; (iii) platelet aggregation is inhibited by the synergic effect of cGMP and cAMP; and (iv) cGMP inhibits PI3K, which is responsible for the activation of integrin $\alpha \mathrm{IIb} \beta 3$, a transmembrane glycoprotein signalling receptor essential for normal platelet function. NO donors also have been shown to inhibit platelet aggregation independently of sGC [72].

Additionally, it is well reported that haemoglobin $(\mathrm{Hb})$ is capable of binding to $\mathrm{NO}$ and its metabolites. S-nitrosothiols and dinitrosyl iron complexes bind to the heme in $\mathrm{Hb}$, working as an NO store, preventing NO oxidation. Moreover, despite the fact that endothelial NO synthesis in venous circulation is disabled because of a low concentration of oxygen, the $\mathrm{Hb}$ stores of $\mathrm{NO}$ guarantee that $\mathrm{NO}$ is available to the venous circulation $[73,74]$. 
Appropriate regulation of NO generation and distribution is thus fundamental for the maintenance of vascular tone and normal blood flow, regulating platelet and leukocyte adhesion to endothelium and, ultimately, the distribution of oxygen and nutrients to the body [75-77]. Additionally, heme is converted to carbon monoxide (CO), free iron, and bilirubin through heme oxygenase (HO-1) action. Although $\mathrm{CO}$ has been reported to induce anti-inflammatory cytokines and downregulate pro-inflammatory cytokines release (reviewed by [78]), its pro-coagulant and anti-fibrinolysis activities (reviewed by [79]) might be substantially involved in the induction of generalized coagulation in sepsis.

Normally, the collateral effects of ROS production are limited because of an armory of protective strategies chiefly facilitated by diverse forms of antioxidant protection and efficient removal and repair mechanisms. However, under circumstances such as excessive inflammation, traumatic injury, and cell/tissue ischaemia, excessive levels of ROS formation can occur to the extent that endogenous protection becomes overwhelmed, a scenario often observed in the critically ill, and particularly so during sepsis. Indeed, there is wellestablished literature demonstrating oxidative and nitroasive modification/damage of biomolecules in the critically ill [80-84]. In addition, the production of DAMPs (damageassociated molecular patterns) and PAMPs (pathogen associated molecular patterns) and subsequent binding to activation of TLRs (toll like receptors) induce increased ROS release by an array of cells, including endothelial cells, platelets, and neutrophils [85]. Such activation further promotes additional ROS production by these cells, creating a selfsustaining and ever-expanding ROS activation system, which further negatively impacts patient clinical presentation [86-89].

As for the systems that generate ROS in sepsis, these are complex, including NADPH oxidase (NOX) and dual oxidase enzymes (DuOX); mitochondrial respiration and dysfunction; the activities of cyclooxygenases and lipoxygenases; xanthine oxidoreductases (XOR); the effects of ischaemia reperfusion injury; NO production by NOS enzymes; and loss of homeostatic control for iron recycling, allowing for production of directly damaging ROS. See Table 1 for specific details. 
Table 1. Main reactive oxygen and nitric species producers.

Enzyme

Nicotinamide adenine

dinucleotide phosphate (NADPH)

oxidase (NOX1-5; DUOX1, 2)

Mitochondrial respiration chain

Cyclooxygenase and Lipoxygenase

anthine, oxidoreductase $(\mathrm{XO})$

dehydrogenase oxidase (XDH)

NOS1 or nNOS (neuronal), NOS2

or iNOS (inducible), and NOS3 or eNOS (endothelial)
Mechanism

Reference

Conversion of $\mathrm{O}_{2}$ to $\mathrm{O}_{2}{ }^{\bullet-}$, NADPH acts as an electron donor. NOX1-4 provide constitutive activity, which is dependent on subunits

NOXO1, p47phox, or p22 phox phosphorylation. Further rearrangement of the subunit complexes p40phox, p67phox, and Rac from the cytosol to the membrane allows for transfer of electrons from the substrate to $\mathrm{O}_{2}$

90-92] NOX5 and Duox activation are calcium-dependent.

Oxygen acts as the terminal electron acceptor of the respiratory chain. The process involves a four-electron reduction of oxygen to water, which can occur in the outer membrane, in the inner membrane, or within the matrix. ROS including $\mathrm{O}_{2}^{\bullet-}, \mathrm{H}_{2} \mathrm{O}_{2}$, and $\bullet \mathrm{OH}^{\circ}$ are produced as intermediates in this ongoing process. Around $1 \%$ of $\mathrm{O}_{2}{ }^{\bullet-}$ exits the mitochondria as a physiological process under

steady-state conditions. Hyperoxia and hypoxia/reperfusion both augment $\mathrm{O}_{2}{ }^{\bullet-}$ release greatly, with the potential for direct effects on cellular redox state and signaling, as well as the conversion to more damaging species through iron catalysis (Fenton reaction).

These enzymes metabolize arachidonic acid (AA) to form prostaglandins, thromboxane, and leukotrienes. The enzymic addition of oxygen as occurs in these processes involves ROS generation with the potential for collateral effects.

In addition, COX and LOX metabolites are known to affect intracellular redox balance by activation of NOX enzymes.

Rate-limiting enzymes responsible for the conversion of hypoxanthine and xanthine to uric acid in the last stages of purine catabolism.

$\mathrm{XDH}$ catalyses these process, utilising NAD+ as a cofactor. $\mathrm{XDH}$ can be readily converted to XO by hyperoxia, by the effects of

ischaemia/reperfusion, or by limited proteolysis. $\mathrm{XO}$ catalyses the same reaction, but uses oxygen as a co-factor rather than $\mathrm{NAD}^{+}$. consequently, $\mathrm{O}_{2} \bullet-$ and $\mathrm{H}_{2} \mathrm{O}_{2}$ are generated as by products and thus influence an array of ROS-related dysfunctions.

\section{Enzymatic production of $\mathrm{NO}$ and regulation of vascular tone.}

Use of l-arginine and $\mathrm{O}_{2}$ as substrates and nicotinamide-adenine-dinucleotide phosphate (NADPH), flavin adenine dinucleotide (FAD) flavin mononucleotide (FMN), and (6R)5,6,7,8-tetrahydrobiopterin (BH4) as reduced cofactors.

When NO is produced by endothelial cells, it diffuses through smooth muscle cells, binding to guanylyl cyclase (GC). GC produces the second messenger, cyclic guanosine 3,5-monophosphate (cGMP). cGMP interacts with protein kinase G (PKG), which promotes the phosphorylation of contractile proteins, resulting in a decrease in cytosolic $\mathrm{Ca}^{2+}$, which stimulates myosin light-chain dephosphorylation, promoting vasorelaxation.

Formed by the reaction between equimolar amounts $\mathrm{NO}$ and $\mathrm{O}_{2}{ }^{-}$, the peroxnitrite ion $\left(\mathrm{ONOO}^{-}\right)$is more reactive and toxic than NO. It modifies proteins and peptides via nitration (of tyrosine) and nitrosylation (of thiol moieties) and, in addition, via hydroxylation reactions involving a species likened to ${ }^{\bullet} \mathrm{OH}$. $\mathrm{ONOO}^{-}$formation and damage is strongly correlated with a range of cardiovascular pathologies. 


\section{The Role of Oxidative and Nitrosative Stress in Sepsis-Related Haemostasis}

\subsection{Glycocalyx}

The glycocalyx of the endothelium is an intravascular lubricant layer, composed of membrane-binding domains and plasma proteins that separate circulating blood from vessel walls. It is a major contributor to cardiovascular homeostasis, controlling thrombus development, vascular permeability, together with the provision of anti-inflammatory and antioxidant defenses $[102,103]$. Severe inflammation promotes glycocalyx shedding, altering structure, and compromising function [102]. Oxidative stress is thought to be a major contributor for this impairment, which ultimately leads to the synthesis and exposure of adhesion molecules and, subsequently, the influx of leukocytes and platelets to the vascular bed $[104,105]$. Indeed, it has been reported that, in diseases where oxidative stress plays an important role, such as sepsis or post-cardiac arrest syndrome, shedding of glycocalyx structures was apparent (see Figure 1) [106].

\subsubsection{Mitochondria}

Mitochondria are the principal site of ROS generation in endothelial cells both in health and during sepsis [107], and numerous studies have reported the impacts of altered mitochondrial activity on the function of blood vessel. For instance, in human coronary arterioles, rotenone and myxotgiazol, inhibitors of mitochondrial complex I and III, respectively, mitigated flow-induced dilatation associated with $\mathrm{O}_{2}{ }^{\bullet-}$ and $\mathrm{H}_{2} \mathrm{O}_{2}$ release, whereas apocynin, an NADPH oxidase inhibitor, did not affect the increase in ROS generation induced by shear stress [108]. Additionally, Lowes et al. showed that human umbilical vein endothelial cell incubated with LPS; promoted elevated ROS generation; lowered mitochondrial membrane potential; and increased the release of cytokines IL-1b, IL-6, IL-8, and IL-10. These effects were all abrogated by MitoQ, a mitochondrial targeted antioxidant [109]. MitoTEMPO, another mitochondrial superoxide scavenger, also ameliorated organ dysfunction and improved the survival rates in a murine model of sepsis involving the CLP model [110]. Additionally, the antioxidant protein paraoxonase-2 (PON2) is involved in the control of oxidative stress, reduction of inflammation, and protection against atherosclerosis. Furthermore, Altenhöfer et al. have demonstrated that PON2 decreased $\mathrm{O}_{2}{ }^{\bullet-}$ generation from the endothelial cells of human mitochondrial complex I and complex III at the inner mitochondrial membrane, supposedly by acting on coenzyme Q10 (CoQ) [111]. In addition, Ebert et al. showed that PON2-knockout mice presented loss of redox homeostasis, endothelial cells' abnormalities with an increase of tissue factor activity, reduction of coagulation times, and increased platelet activity [112].

\subsubsection{NADPH Oxidase}

This multisubunit enzyme is also reported to promote ROS generation in the endothelium. Wu et al. showed that, in microvascular endothelial cells when stimulated with LPS, the ROS scavenger ascorbate abrogated NOX1 activity; p47phox expression; and, consequently, decreased ROS production [113]. The upregulation of NOX1 by LPS, TNF- $\alpha$, and IL- $1 \alpha$ has also been shown to induce mitochondrial $\mathrm{O}_{2}{ }^{\bullet-}$ generation in pig pulmonary arteries [114].

During sepsis, the endothelium generates high levels of tissue factor pathway inhibitor (TFPI), together with NO and prostacyclin, in order to maintain an antithrombotic capacity. However, in sepsis, endothelium anticoagulant factors such as TFPI do not operate appropriately, thereby allowing leukocyte and platelet adhesion and, consequently, the release of tissue factor and the formation of microthrombi $[87,111]$. Interestingly, incubation of endothelial cells with xanthine/xanthine oxidase a potent source of $\mathrm{O}_{2}{ }^{\bullet-}$ and $\mathrm{H}_{2} \mathrm{O}_{2}$, inhibiting TFPI [115].

\subsection{3. iNOS and NO}

The glycocalyx can also release toxic levels of NO via iNOS activity, which causes hypotension and circulatory failure, subsequent disruption of oxygen distribution impairment 
of the endothelial barrier system, and damage to various organs [77,116]. Additionally, greatly elevated levels of NO promote a substantial inhibition of platelet activity, leading to an extensive bleeding time, hemorrhage, and potentially death $[117,118]$. Furthermore, in addition to endothelial cells, neutrophils also contain iNOS, which further contributes to the NO pool in sepsis and reduces the interaction between neutrophils and the endothelium [119]. In this regard, a study using a cecal ligation and puncture (CLP) model of sepsis in rodents showed that increases in NO production inhibited neutrophil rolling and, consequently, abolished adhesion to the endothelium. Importantly, treatment with aminoguanidine, an NO inhibitor, was able to restore neutrophil function and decreased mortality [120]. Another relevant pathophysiological RNS species is $\mathrm{ONOO}^{-}$, which is formed by the reaction between equimolar levels of $\mathrm{O}_{2}{ }^{\bullet-}$ and $\mathrm{NO}$; this directly damaging species when formed is associated with cytotoxic effects and tissue damage $[77,116,121]$.

\subsection{Platelets}

Platelets also play a key role in ROS production during sepsis, with both external and internal ROS production reported to modulate platelet activity through the integrin $\alpha \mathrm{IIb} \beta_{3}$ (fibrinogen receptor), GVI (collagen receptor), and GPIb $\alpha$ (von Willebrand factor receptor) [122,123]. As such, platelets incubated with LPS from Chlamydia pneumoniae, Proteus mirabilis, or Escherichia coli all demonstrated elevated levels of ROS generation. In addition, LPS induced ROS generation by platelets and increased platelet-fibrinogen binding and P-selectin exposure, all of which was abrogated by superoxide dismutase and catalase $[107,122]$. Moreover, mice pre-treated with the antioxidant $N$-acetylcysteine (NAC) prior to injection with LPS re-established normal levels of platelet ROS production and aggregation [124].

One of the main roles of platelets in sepsis is to promote the activation and migration of neutrophils to the sites of tissue injury and to stimulate neutrophil NETs' release and ROS generation $[125,126]$. Additionally, both in experimental sepsis and in patients recovering from septic shock, neutrophils also generate extensive levels of production ROS via NADPH oxidase (NOX2), independent of any platelet stimulus. Importantly, neutrophils' surface receptors, such as integrin, Fc receptors, and members of the G-protein-coupled receptors family, have all been shown to promote the stimulation of neutrophil-NADPH oxidase activation [127].

It is well known that platelets contain NADPH oxidases, more specifically NOX1, NOX2, and NOX4. However, any role of NOXs in platelet signalling remains somewhat contradictory [128-131]. Some studies have reported a fundamental role in experimental platelet ROS production, while others have shown that endotoxemia in rats increased TNF$\alpha$ levels and promoted platelet-NADPH oxidase activity, via cGMP-PKG and PKC-p47phox signalling pathways $[22,124,132]$. NADPH oxidase (NOX2) activity within neutrophils and specifically ROS production has been suggested to stimulate NETosis, as seen in both human and experimental sepsis $[104,133]$. However, this assertion is a subject of ongoing debate, as other studies have shown that inhibition of neutrophil NADPH oxidase did not affect NETs' release [134,135].

Moreover, in patients with sepsis, soluble plasma factor-induced uncoupling of platelet mitochondria increases respiratory capacity, a feature that was more intense in non-survivors. In addition, platelet mitochondria function was reported to be associated with organ failure and elevated lactate levels [136,137].

\section{Conclusions}

This review provides some evidence linking aspects of oxidative/nitrosative stress, and the onset and establishment of hemostasis in sepsis. Abnormal coagulation events including DIC impair tissue prefusion, which may ultimately result in multiple organ dysfunction and death. The combination of greatly elevated levels of ROS and RNS production resulting from an overstimulation of the inflammatory response beyond the limits of homeostatic control, in part due to depletion of finite antioxidant reserves, results 
in a pro-oxidant environment. Under these circumstances, redox-based stress responses become detrimental, with an array of negative impacts including the over-stimulation of coagulation and further expansive inflammatory systems' activation; endothelium dysfunction and platelet and neutrophil activation, including the formation of neutrophil NETs, all contribute to these responses.

Diagnosis and treatment of sepsis remain a significant challenge for healthcare providers globally, and gaining greater insights into key aspects of complicated proinflammatory processes that ensue during onset and progression of disease remains a priority. Targeting the drivers of excessive oxidative/nitrosative stress using antioxidant treatments is an obvious therapeutic avenue. However, while beneficial responses can be demonstrated for an array of adverse endpoints including clotting dysfunction using in vitro and in vivo models, clinical trials have to date been somewhat disappointing; a more nuanced approach may offer a way forward. In this regard, the advent of antioxidants that are specific for key compartments/organelles such as mitochondria, combinational approaches to operative in differing extracellular and intracellular compartments, prophylactic usage in risk groups, and/or the timing and/or duration of use may provide some measure of success (see Figure 2 and Table 2).

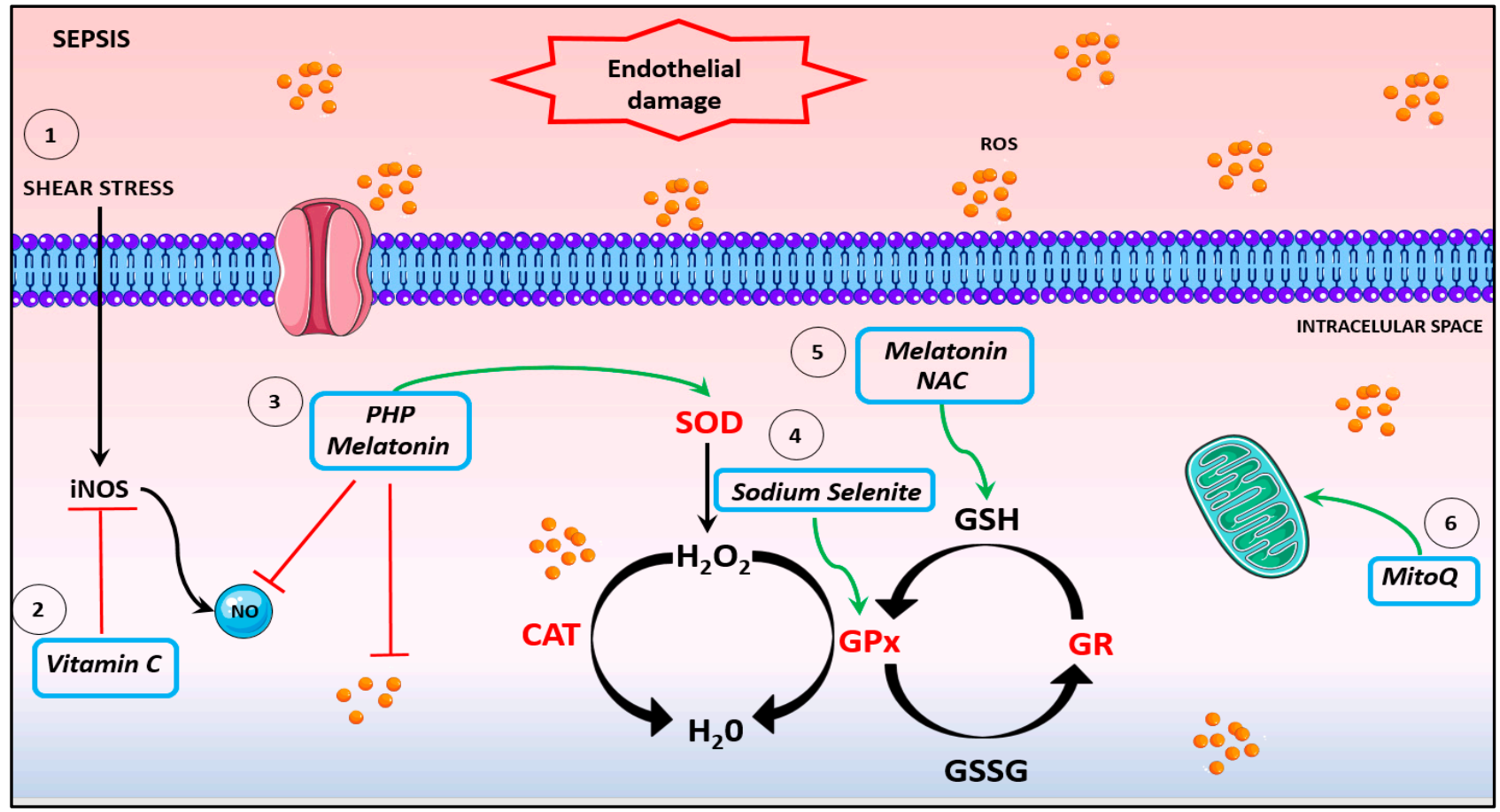

Figure 2. Potential antioxidants therapies. (1) The inflammatory scenario of sepsis induces shear stress, causing endothelium damage and activation of iNOS, leading to an NO boosting. (2) Vitamin $\mathrm{C}$ is an antioxidant acting on iNOS inhibition expression, improving microvascular dysfunction and ameliorating hypotension. (3) The compound PHP and melatonin sequestrate NO and promote SOD activation. (4) Sodium selenite promotes an increase in GPx activity. (5). NAC and melatonin restore GSH levels and inhibit platelet and neutrophil dysfunction. (6). MitoQ enhances mitochondrial respiration and restores mitochondrial dysfunction. NO: nitric oxide. CAT: catalase. SOD: superoxide dismutase. GPx: glutathione peroxidase. GR: glutathione reductase. 
Table 2. Potential antioxidant therapies.

\begin{tabular}{|c|c|c|c|}
\hline Therapy & Mechanism & Positive Effect & Why is Not it Been Clinically Used? \\
\hline Vitamin C & $\begin{array}{l}\text { Potent ROS scavenging antioxidant } \\
\text { agent [138] }\end{array}$ & $\begin{array}{l}\text { Septic shock patients treated with } \mathrm{ANON}^{\circledR} \text {, an antioxidant-enriched } \\
\text { concentrated liquid diet with high concentrations of vitamin } C \text { and } \mathrm{E} \text {, } \\
\text { demonstrated a restoration of vitamin } \mathrm{C} \text { radical levels in serum and a reduction } \\
\text { in MOF [139]. Septic animals treated with vitamin C showed an improvement } \\
\text { in microvascular dysfunction and microvascular permeability barrier integrity, } \\
\text { inhibition of iNOS expression, and ameliorated hypotension }[89,113,138,140] \text {. } \\
\text { The vasodilatation and reduction in vitamin C plasma concentration after low } \\
\text { doses of LPS administration in healthy volunteers were reversed by } \\
\text { co-administration of vitamin C [141]. }\end{array}$ & Limited clinical trials \\
\hline Seleniun & $\begin{array}{l}\text { A micronutrient fundamental for GPx } \\
\text { synthesis }[142,143]\end{array}$ & $\begin{array}{l}\text { The administration of high levels of sodium selenite intravenously showed an } \\
\text { increase in blood selenium concentration and GPx activity and significantly } \\
\text { decreased mortality of septic patients with DIC [144]. }\end{array}$ & $\begin{array}{l}\text { Seleniun decreased the infection in nonseptic } \\
\text { patients only. Clinical trials did not show any } \\
\text { improvement in outcomes in a general septic } \\
\text { patient population [145] }\end{array}$ \\
\hline $\begin{array}{l}N \text {-acetylcysteine } \\
\text { (NAC) }\end{array}$ & $\begin{array}{l}\text { Antioxidant is able to restore the levels } \\
\text { of GSH in the cells and also acts as an } \\
\text { anti-inflammatory agent [146] }\end{array}$ & $\begin{array}{l}\text { The treatment of rats with NAC, } 30 \text { min after LPS injection, re-established their } \\
\text { ROS generation levels and platelet aggregation [124]. NAC treatment in rats } \\
\text { decreased neutrophil infiltration and leukocyte adherence, ameliorated } \\
\text { mitochondrial dysfunction, and decreased oxidative stress [147-150]. NAC } \\
\text { administration by septic patients reduced lipid peroxidation, induced tissue } \\
\text { oxygenation, ameliorated cardiac function, and decreased the mortality rate } \\
\text { [151-154]. }\end{array}$ & $\begin{array}{l}\text { Conflicting results: some studies showed that } \\
\text { NAC did not improve outcome for patients or } \\
\text { affect levels of cytokines' release [155]. NAC } \\
\text { can also worsen organ failure [156]. Findings } \\
\text { need to be confirmed in larger clinical trials }\end{array}$ \\
\hline MitoQ & Targets mitochondrial dysfunction [157] & $\begin{array}{l}\text { Endotoxemic rats that received MitoQ by i.v. administration demonstrated } \\
\text { enhancement in mitochondria respiration, decreased levels of oxidative stress } \\
\text { and IL-6, and improved organ dysfunction }[157,158] \text {. }\end{array}$ & There are no data from human studies \\
\hline $\begin{array}{c}\text { Superoxide } \\
\text { dismutase (SOD) }\end{array}$ & $\begin{array}{c}\text { Converts superoxide radical into } \\
\text { hydrogen peroxide and molecular } \\
\text { oxygen }\left(\mathrm{O}_{2}\right) \text {, while the catalase and } \\
\text { peroxidases convert hydrogen peroxide } \\
\text { into water }[159,160]\end{array}$ & $\begin{array}{l}\text { The M40401 SOD mimetic restored vascular reactivity, regulated arterial } \\
\text { pressure, and decreased mortality levels of rats infected with E. coli [161] }\end{array}$ & There are no data from human studies \\
\hline
\end{tabular}


Table 2. Cont.

\begin{tabular}{|c|c|c|c|}
\hline Therapy & Mechanism & Positive Effect & Why is Not it Been Clinically Used? \\
\hline $\begin{array}{l}\text { Nitric oxide } \\
\text { scavenger }\end{array}$ & $\begin{array}{l}\text { The compound pyridoxylated } \\
\text { haemoglobin polyoxyethylene (PHP) is } \\
\text { a chemically altered human-derived } \\
\text { hemoglobin used as an NO scavenger } \\
\text { and SOD mimetic [162]. }\end{array}$ & $\begin{array}{l}\text { In a Pseudomona aeruginosa sepsis model in sheep, infusion of PHP for } 48 \mathrm{~h} \\
\text { restored a low mean arterial pressure and improved the systemic vascular } \\
\text { resistance [163,164]. In phase I/II clinical trials, PHP increased blood pressure } \\
\text { and diminished catecholamine requirement [165]; in a phase III trial with } \\
377 \text { patients, PHP reduced the necessity of vasopressor use [166]. }\end{array}$ & $\begin{array}{c}\text { Despite some positive results, after } 28 \text { days of } \\
\text { therapy with PHP, there was no benefit and } \\
\text { indeed mortality rates increased, with a SOFA } \\
\text { score higher than } 13 \text { [166] }\end{array}$ \\
\hline Melatonin & $\begin{array}{l}\text { Secreted during the night, melatonin is a } \\
\text { hormone produced by the pineal gland. } \\
\text { It possesses anti-inflammatory } \\
\text { properties and demonstrates antioxidant } \\
\text { functions, acting as both an ROS and } \\
\text { RNS scavenger [167]. }\end{array}$ & $\begin{array}{l}\text { In septic rats induced by CLP, administration of melatonin improved organ } \\
\text { injury; an effect that was ascribed to the capacity of melatonin to enhance GSH } \\
\text { levels and to inhibit neutrophil aggregation [168]. In a placebo-controlled study } \\
\text { with } 12 \text { healthy volunteers, the group that received melatonin before LPS } \\
\text { showed lower levels of inflammatory markers and oxidative stress compared } \\
\text { with the saline control group }[138,169] \text {. }\end{array}$ & Lack of clinical trials \\
\hline
\end{tabular}


Funding: This study was supported by the British Heart Foundation and Coordination for the Improvement of Personnel Higher Education Personnel (CAPES).

Conflicts of Interest: The authors declare no conflict of interest.

\section{References}

1. Bauer, M.; Gerlach, H.; Vogelmann, T.; Preissing, F.; Stiefel, J.; Adam, D. Mortality in Sepsis and Septic Shock in Europe, North America and Australia between 2009 and 2019-Results from a Systematic Review and Meta-Analysis. Crit. Care 2020, $24,239$. [CrossRef]

2. Dave, M.; Barry, S.; Coulthard, P.; Daniels, R.; Greenwood, M.; Seoudi, N.; Walton, G.; Patel, N. An Evaluation of Sepsis in Dentistry. Br. Dent. J. 2021, 230, 351-357. [CrossRef] [PubMed]

3. Rhee, C.; Dantes, R.; Epstein, L.; Murphy, D.J.; Seymour, C.W.; Iwashyna, T.J.; Kadri, S.S.; Angus, D.C.; Danner, R.L.; Fiore, A.E.; et al. Incidence and Trends of Sepsis in US Hospitals Using Clinical vs. Claims Data, 2009-2014. JAMA-J. Am. Med. Assoc. 2017, 318, 1241-1249. [CrossRef] [PubMed]

4. $\quad$ Daniels, R. Survive Sepsis; United Kingdom Sepsis Trust: Birmingham, UK, 2014; ISBN 9780992815509.

5. Angus, D.C.; van der Poll, T. Severe Sepsis and Septic Shock. N. Engl. J. Med. 2013, 369, 840-851. [CrossRef]

6. Cecconi, M.; Evans, L.; Levy, M.; Rhodes, A. Sepsis and Septic Shock. Lancet 2018, 392, 75-87. [CrossRef]

7. Vincent, J.; Moreno, R.; Takala, J.; de Mendonça, A.; Bruining, H.; Reinhart, C.; Suter, P.; Thijs, L. The SOFA (Sepsis-Related Organ Failure Assessment) Score to Describe Organ Dysfunction/Failure. On Behalf of the Working Group on Sepsis-Related Problems of the European Society of Intensive Care Medicine. Intensive Care Med. 1996, 22, 707-710. [CrossRef]

8. Okabayashi, K.; Wada, H.; Ohta, S.; Shiku, H.; Nobori, T.; Maruyama, K. Hemostatic Markers and the Sepsis-related Organ Failure Assessment Score in Patients with Disseminated Intravascular Coagulation in an Intensive Care Unit. Am. J. Hematol. 2004, 76, 225-229. [CrossRef]

9. Levi, M.; Cate, H. Ten Disseminated Intravascular Coagulation. N. Engl. J. Med. 1999, 341, 586-592. [CrossRef]

10. Gando, S.; Levi, M.; Toh, C.H. Disseminated Intravascular Coagulation. Nat. Rev. Dis. Primers 2016, 2, 16037. [CrossRef]

11. Hoshino, K.; Kitamura, T.; Nakamura, Y.; Irie, Y.; Matsumoto, N.; Kawano, Y.; Ishikura, H. Usefulness of Plasminogen Activator Inhibitor-1 as a Predictive Marker of Mortality in Sepsis. J. Intensive Care 2017, 5, 42. [CrossRef]

12. Robbie, L.A.; Dummer, S.; Booth, N.A.; Adey, G.D.; Bennett, B. Plasminogen Activator Inhibitor 2 and Urokinase-Type Plasminogen Activator in Plasma and Leucocytes in Patients with Severe Sepsis. Br. J. Haematol. 2000, 109, 342-348. [CrossRef]

13. Raaphorst, J.; Johan Groeneveld, A.B.; Bossink, A.W.; Erik Hack, C. Early Inhibition of Activated Fibrinolysis Predicts Microbial Infection, Shock and Mortality in Febrile Medical Patients. Thromb. Haemost. 2001, 86, 543-549. [CrossRef]

14. Lados-Krupa, A.; Konieczynska, M.; Chmiel, A.; Undas, A. Increased Oxidation as an Additional Mechanism Underlying Reduced Clot Permeability and Impaired Fibrinolysis in Type 2 Diabetes. J. Diabetes Res. 2015, 2015, 456189. [CrossRef] [PubMed]

15. Gando, S.; Saitoh, D.; Ishikura, H.; Ueyama, M.; Otomo, Y.; Oda, S.; Kushimoto, S.; Tanjoh, K.; Mayumi, T.; Ikeda, T.; et al. A Randomized, Controlled, Multicenter Trial of the Effects of Antithrombin on Disseminated Intravascular Coagulation in Patients with Sepsis. Crit. Care 2013, 17, R297. [CrossRef]

16. Masuda, T.; Shoko, T. Clinical Investigation of the Utility of a Pair of Coagulation-Fibrinolysis Markers for Definite Diagnosis of Sepsis-Induced Disseminated Intravascular Coagulation: A Single-Center, Diagnostic, Prospective, Observational Study. Thromb. Res. 2020, 192, 116-121. [CrossRef] [PubMed]

17. Matsuda, K.; Kurokawa, M. Underlying Disease and Clinical Phenotypes of Disseminated Intravascular Coagulation. JMA J. 2020, 3, 357-358. [CrossRef]

18. Ohbe, H.; Yamakawa, K.; Taniguchi, K.; Morita, K.; Matsui, H.; Fushimi, K. Underlying Disorders, Clinical Phenotypes, and Treatment Diversity among Patients with Disseminated Intravascular Coagulation. JMA J. 2020, 3, 321-329. [CrossRef] [PubMed]

19. Jackson Chornenki, N.L.; Dwivedi, D.J.; Kwong, A.C.; Zamir, N.; Fox-Robichaud, A.E.; Liaw, P.C. Identification of Hemostatic Markers That Define the Pre-DIC State: A Multi-Center Observational Study. J. Thromb. Haemost. 2020, 18, 2524-2531. [CrossRef]

20. Smith, L. Disseminated Intravascular Coagulation. Semin. Oncol. Nurs. 2021, 37, 151135. [CrossRef] [PubMed]

21. Yamakawa, K.; Yoshimura, J.; Ito, T.; Hayakawa, M.; Hamasaki, T.; Fujimi, S. External Validation of the Two Newly Proposed Criteria for Assessing Coagulopathy in Sepsis. Thromb. Haemost. 2019, 119, 203-212. [CrossRef]

22. Naime, A.C.A.; Ganaes, J.O.F.; Lopes-Pires, M.E. Sepsis: The Involvement of Platelets and the Current Treatments. Curr. Mol. Pharmacol. 2018, 11, 261-269. [CrossRef]

23. Helms, J.; Severac, F.; Merdji, H.; Clere-Jehl, R.; François, B.; Mercier, E.; Quenot, J.P.; Meziani, F. Performances of Disseminated Intravascular Coagulation Scoring Systems in Septic Shock Patients. Ann. Intensive Care 2020, 10, 92. [CrossRef]

24. Abrams, S.T.; Morton, B.; Alhamdi, Y.; Alsabani, M.; Lane, S.; Welters, I.D.; Wang, G.; Toh, C.H. A Novel Assay for Neutrophil Extracellular Trap Formation Independently Predicts Disseminated Intravascular Coagulation and Mortality in Critically Ill Patients. Am. J. Respir. Crit. Care Med. 2019, 200, 869-880. [CrossRef]

25. Patel, P.; Walborn, A.; Rondina, M.; Fareed, J.; Hoppensteadt, D. Markers of Inflammation and Infection in Sepsis and Disseminated Intravascular Coagulation. Clin. Appl. Thromb. Hemost. 2019, 25, 1-6. [CrossRef] [PubMed] 
26. Yang, X.; Cheng, X.; Tang, Y.; Qiu, X.; Wang, Y.; Kang, H.; Wu, J.; Wang, Z.; Liu, Y.; Chen, F.; et al. Bacterial Endotoxin Activates the Coagulation Cascade through Gasdermin D-Dependent Phosphatidylserine Exposure. Immunity 2019, 51, 983-996.e6. [CrossRef] [PubMed]

27. Kinasewitz, G.T.; Yan, S.B.; Basson, B.; Comp, P.; Russell, J.A.; Cariou, A.; Um, S.L.; Utterback, B.; Laterre, P.F.; Dhainaut, J.F. Universal Changes in Biomarkers of Coagulation and Inflammation Occur in Patients with Severe Sepsis, Regardless of Causative Micro-Organism [ISRCTN74215569]. Crit. Care 2004, 8, 82-90. [CrossRef]

28. Levi, M.; van der Poll, T. Coagulation and Sepsis. Thromb. Res. 2017, 149, 38-44. [CrossRef]

29. Scully, M.; Levi, M. How We Manage Haemostasis during Sepsis. Br. J. Haematol. 2019, 185, 209-218. [CrossRef] [PubMed]

30. Nieuwland, R.; Gardiner, C.; Dignat-George, F.; Mullier, F.; Mackman, N.; Woodhams, B.; Thaler, J. Toward Standardization of Assays Measuring Extracellular Vesicle-Associated Tissue Factor Activity. J. Thromb. Haemost. 2019, 17, 1261-1264. [CrossRef]

31. Kay, J.G.; Grinstein, S. Phosphatidylserine-Mediated Cellular Signaling. Adv. Exp. Med. Biol. 2013, 991, 177-193. [CrossRef]

32. Delabranche, X.; Boisramé-Helms, J.; Asfar, P.; Berger, A.; Mootien, Y.; Lavigne, T.; Grunebaum, L.; Lanza, F.; Gachet, C.; Freyssinet, J.M.; et al. Microparticles Are New Biomarkers of Septic Shock-Induced Disseminated Intravascular Coagulopathy. Intensive Care Med. 2013, 39, 1695-1703. [CrossRef]

33. Matsumoto, H.; Yamakawa, K.; Ogura, H.; Koh, T.; Matsumoto, N.; Shimazu, T. Enhanced Expression of Cell-Specific Surface Antigens on Endothelial Microparticles in Sepsis-Induced Disseminated Intravascular Coagulation. Shock 2015, 43, 443-449. [CrossRef]

34. Walborn, A.; Rondina, M.; Mosier, M.; Fareed, J.; Hoppensteadt, D. Endothelial Dysfunction Is Associated with Mortality and Severity of Coagulopathy in Patients with Sepsis and Disseminated Intravascular Coagulation. Clin. Appl. Thromb. Hemost. 2019, 25, 1-9. [CrossRef] [PubMed]

35. VanTeeffelen, J.W.; Brands, J.; Stroes, E.S.; Vink, H. Endothelial Glycocalyx: Sweet Shield of Blood Vessels. Trends Cardiovasc. Med. 2007, 17, 101-105. [CrossRef]

36. Lupu, F.; Kinasewitz, G.; Dormer, K. The Role of Endothelial Shear Stress on Haemodynamics, Inflammation, Coagulation and Glycocalyx during Sepsis. J. Cell. Mol. Med. 2020, 24, 12258-12271. [CrossRef] [PubMed]

37. Sampei, S.; Okada, H.; Tomita, H.; Takada, C.; Suzuki, K.; Kinoshita, T.; Kobayashi, R.; Fukuda, H.; Kawasaki, Y.; Nishio, A.; et al. Endothelial Glycocalyx Disorders May Be Associated With Extended Inflammation During Endotoxemia in a Diabetic Mouse Model. Front. Cell Dev. Biol. 2021, 9, 623582. [CrossRef] [PubMed]

38. Kushimoto, S.; Abe, T.; Ogura, H.; Shiraishi, A.; Saitoh, D.; Fujishima, S.; Mayumi, T.; Hifumi, T.; Shiino, Y.; Nakada, T.-A.; et al. Impact of Blood Glucose Abnormalities on Outcomes and Disease Severity in Patients with Severe Sepsis: An Analysis from a Multicenter, Prospective Survey of Severe Sepsis. PLoS ONE 2020, 15, e0229919. [CrossRef]

39. Iba, T.; Connors, J.M.; Nagaoka, I.; Levy, J.H. Recent Advances in the Research and Management of Sepsis-Associated DIC. Int. J. Hematol. 2021, 113, 24-33. [CrossRef]

40. Hou, P.C.; Filbin, M.R.; Wang, H.; Ngo, L.; Aird, W.C.; Shapiro, N.I.; Wang, H.; Huang, D.T.; Angus, D.C.; Kellum, J.A.; et al. Endothelial Permeability and Hemostasis in Septic Shock: Results From the ProCESS Trial. Chest 2017, 152, 22-31. [CrossRef]

41. Portier, I.; Campbell, R.A. Role of Platelets in Detection and Regulation of Infection. Arterioscler. Thromb. Vasc. Biol. 2020, 41, 70-78. [CrossRef]

42. Ma, R.; Xie, R.; Yu, C.; Si, Y.; Wu, X.; Zhao, L.; Yao, Z.; Fang, S.; Chen, H.; Novakovic, V.; et al. Phosphatidylserine-Mediated Platelet Clearance by Endothelium Decreases Platelet Aggregates and Procoagulant Activity in Sepsis. Sci. Rep. 2017, 7, 4978. [CrossRef]

43. Puskarich, M.A.; Cornelius, D.C.; Bandyopadhyay, S.; McCalmon, M.; Tramel, R.; Dale, W.D.; Jones, A.E. Phosphatidylserine Expressing Platelet Microparticle Levels at Hospital Presentation Are Decreased in Sepsis Non-Survivors and Correlate with Thrombocytopenia. Thromb. Res. 2018, 168, 138-144. [CrossRef] [PubMed]

44. Tsirigotis, P.; Chondropoulos, S.; Frantzeskaki, F.; Stamouli, M.; Gkirkas, K.; Bartzeliotou, A.; Papanikolaou, N.; Atta, M.; Papassotiriou, I.; Dimitriadis, G.; et al. Thrombocytopenia in Critically Ill Patients with Severe Sepsis/Septic Shock: Prognostic Value and Association with a Distinct Serum Cytokine Profile. J. Crit. Care 2016, 32, 9-15. [CrossRef]

45. Lopes-Pires, M.E.; Naime, A.C.A.; Cardelli, N.J.A.; Anjos, D.J.; Antunes, E.; Marcondes, S. PKC and AKT Modulate CGMP/PKG Signaling Pathway on Platelet Aggregation in Experimental Sepsis. PLoS ONE 2015, 10, e0137901. [CrossRef] [PubMed]

46. Naime, A.C.A.; Bonfitto, P.H.L.; Solon, C.; Lopes-Pires, M.E.; Anhê, G.F.; Antunes, E.; Marcondes, S. Tumor Necrosis Factor Alpha Has a Crucial Role in Increased Reactive Oxygen Species Production in Platelets of Mice Injected with Lipopolysaccharide. Platelets 2019, 30, 1047-1052. [CrossRef] [PubMed]

47. Laursen, M.A.; Larsen, J.B.; Larsen, K.M.; Hvas, A.M. Platelet Function in Patients with Septic Shock. Thromb. Res. 2020, 185, 33-42. [CrossRef]

48. Bardoel, B.W.; Kenny, E.F.; Sollberger, G.; Zychlinsky, A. The Balancing Act of Neutrophils. Cell Host Microbe 2014, 15, 526-536. [CrossRef]

49. Metzler, K.D.; Goosmann, C.; Lubojemska, A.; Zychlinsky, A.; Papayannopoulos, V. Myeloperoxidase-Containing Complex Regulates Neutrophil Elastase Release and Actin Dynamics during NETosis. Cell Rep. 2014, 8, 883-896. [CrossRef]

50. Xie, T.; Duan, Z.; Sun, S.; Chu, C.; Ding, W. $\beta$-Lactams Modulate Neutrophil Extracellular Traps Formation Mediated by MTOR Signaling Pathway. Biochem. Biophys. Res. Commun. 2021, 534, 408-414. [CrossRef] 
51. Yipp, B.G.; Petri, B.; Salina, D.; Jenne, C.N.; Scott, B.N.V.; Zbytnuik, L.D.; Pittman, K.; Asaduzzaman, M.; Wu, K.; Meijndert, H.C.; et al. Infection-Induced NETosis Is a Dynamic Process Involving Neutrophil Multitasking in Vivo. Nat. Med. 2012, 18, 1386-1393. [CrossRef]

52. Shimizu, M.; Konishi, A.; Nomura, S. Examination of Biomarker Expressions in Sepsis-Related DIC Patients. Int. J. Gen. Med. 2018, 11, 353-361. [CrossRef] [PubMed]

53. Jiao, Y.; Li, W.; Wang, W.; Tong, X.; Xia, R.; Fan, J.; Du, J.; Zhang, C.; Shi, X. Platelet-Derived Exosomes Promote Neutrophil Extracellular Trap Formation during Septic Shock. Crit. Care 2020, 24, 380. [CrossRef] [PubMed]

54. Rodrigues, D.A.S.; Prestes, E.B.; Gama, A.M.S.; de Souza Silva, L.; Pinheiro, A.A.S.; Ribeiro, J.M.C.; Campos, R.M.P.; PimentelCoelho, P.M.; de Souza, H.S.; Dicko, A.; et al. CXCR4 and MIF Are Required for Neutrophil Extracellular Trap Release Triggered by Plasmodium-Infected Erythrocytes. PLoS Pathog. 2020, 16, e1008230. [CrossRef]

55. Colón, D.F.; Wanderley, C.W.; Franchin, M.; Silva, C.M.; Hiroki, C.H.; Castanheira, F.V.S.; Donate, P.B.; Lopes, A.H.; Volpon, L.C.; Kavaguti, S.K.; et al. Neutrophil Extracellular Traps (NETs) Exacerbate Severity of Infant Sepsis. Crit. Care 2019, 23, 113. [CrossRef]

56. Huang, H.; Tohme, S.; Al-Khafaji, A.B.; Tai, S.; Loughran, P.; Chen, L.; Wang, S.; Kim, J.; Billiar, T.; Wang, Y.; et al. DamageAssociated Molecular Pattern-Activated Neutrophil Extracellular Trap Exacerbates Sterile Inflammatory Liver Injury. Hepatology 2015, 62, 600-614. [CrossRef]

57. Shrestha, B.; Ito, T.; Kakuuchi, M.; Totoki, T.; Nagasato, T.; Yamamoto, M.; Maruyama, I. Recombinant Thrombomodulin Suppresses Histone-Induced Neutrophil Extracellular Trap Formation. Front. Immunol. 2019, 10, 2535. [CrossRef]

58. Okeke, E.B.; Louttit, C.; Fry, C.; Najafabadi, A.H.; Han, K.; Nemzek, J.; Moon, J.J. Inhibition of Neutrophil Elastase Prevents Neutrophil Extracellular Trap Formation and Rescues Mice from Endotoxic Shock. Biomaterials 2020, 238, 119836. [CrossRef] [PubMed]

59. Kumar, S.; Gupta, E.; Kaushik, S.; Srivastava, V.K.; Saxena, J.; Mehta, S.; Jyoti, A. Quantification of NETs Formation in Neutrophil and Its Correlation with the Severity of Sepsis and Organ Dysfunction. Clin. Chim. Acta 2019, 495, 606-610. [CrossRef] [PubMed]

60. Chirivi, R.G.S.; van Rosmalen, J.W.G.; van der Linden, M.; Euler, M.; Schmets, G.; Bogatkevich, G.; Kambas, K.; Hahn, J.; Braster, Q.; Soehnlein, O.; et al. Therapeutic ACPA Inhibits NET Formation: A Potential Therapy for Neutrophil-Mediated Inflammatory Diseases. Cell. Mol. Immunol. 2020, 18, 1528-1544. [CrossRef]

61. Locke, M.; Francis, R.J.; Tsaousi, E.; Longstaff, C. Fibrinogen Protects Neutrophils from the Cytotoxic Effects of Histones and Delays Neutrophil Extracellular Trap Formation Induced by Ionomycin. Sci. Rep. 2020, 10, 11694. [CrossRef]

62. Ode, Y.; Aziz, M.; Jin, H.; Arif, A.; Nicastro, J.G.; Wang, P. Cold-Inducible RNA-Binding Protein Induces Neutrophil Extracellular Traps in the Lungs during Sepsis. Sci. Rep. 2019, 9, 6252. [CrossRef]

63. Levi, M.; Scully, M.; Singer, M. The Role of ADAMTS-13 in the Coagulopathy of Sepsis. J. Thromb. Haemost. 2018, 16, 646-651. [CrossRef]

64. Hakkim, A.; Fürnrohr, B.G.; Amann, K.; Laube, B.; Abed, U.A.; Brinkmann, V.; Herrmann, M.; Voll, R.E.; Zychlinsky, A. Impairment of Neutrophil Extracellular Trap Degradation Is Associated with Lupus Nephritis. Proc. Natl. Acad. Sci. USA 2010, 107, 9813-9818. [CrossRef]

65. Müller, F.; Mutch, N.J.; Schenk, W.A.; Smith, S.A.; Esterl, L.; Spronk, H.M.; Schmidbauer, S.; Gahl, W.A.; Morrissey, J.H.; Renné, T. Platelet Polyphosphates Are Proinflammatory and Procoagulant Mediators In Vivo. Cell 2009, 139, 1143-1156. [CrossRef] [PubMed]

66. Smith, S.A.; Mutch, N.J.; Baskar, D.; Rohloff, P.; Docampo, R.; Morrissey, J.H. Polyphosphate Modulates Blood Coagulation and Fibrinolysis. Proc. Natl. Acad. Sci. USA 2006, 103, 903-908. [CrossRef] [PubMed]

67. Finkelstein, E.; Rosen, G.M.; Rauckman, E.J. Spin Trapping of Superoxide and Hydroxyl Radical: Practical Aspects. Arch. Biochem. Biophys. 1980, 200, 1-16. [CrossRef]

68. Griendling, K.K.; Touyz, R.M.; Zweier, J.L.; Dikalov, S.; Chilian, W.; Chen, Y.R.; Harrison, D.G.; Bhatnagar, A. Measurement of Reactive Oxygen Species, Reactive Nitrogen Species, and Redox-Dependent Signaling in the Cardiovascular System: A Scientific Statement from the American Heart Association. Circ. Res. 2016, 119, e39-e75. [CrossRef] [PubMed]

69. Kohen, R.; Nyska, A. Oxidation of Biological Systems: Oxidative Stress Phenomena, Antioxidants, Redox Reactions, and Methods for Their Quantification. Toxicol. Pathol. 2002, 30, 620-650. [CrossRef]

70. Nathan, C. Specificity of a Third Kind: Reactive Oxygen and Nitrogen Intermediates in Cell Signaling. J. Clin. Investig. 2003, 111, 769-778. [CrossRef]

71. Nathan, C.; Xie, Q.W. Regulation of Biosynthesis of Nitric Oxide. J. Biol. Chem. 1994, 269, 13725-13728. [CrossRef]

72. Gkaliagkousi, E.; Ritter, J.; Ferro, A. Platelet-Derived Nitric Oxide Signaling and Regulation. Circ. Res. 2007, 101, 654-662. [CrossRef] [PubMed]

73. Doctor, A.; Platt, R.; Sheram, M.L.; Eischeid, A.; McMahon, T.; Maxey, T.; Doherty, J.; Axelrod, M.; Kline, J.; Gurka, M.; et al. Hemoglobin Conformation Couples Erythrocyte S-Nitrosothiol Content to O2 Gradients. Proc. Natl. Acad. Sci. USA 2005, 102, 5709-5714. [CrossRef] [PubMed]

74. Jia, Y.; Xu, L.; Turner, D.J.; Martin, J.G. Endogenous Nitric Oxide Contributes to Strain-Related Differences in Airway Responsiveness in Rats. J. Appl. Physiol. 1996, 80, 404-410. [CrossRef]

75. Eiserich, J.P.; Hayakawa, K.A.; Cross, C.E. Sepsis and Hypotension: Enter Kynurenine, Move over Nitric Oxide. Crit. Care Med. 2011, 39, 2767-2769. [CrossRef] 
76. Titheradge, M.A. Nitric Oxide in Septic Shock. Biochim. Biophys. Acta-Bioenerg. 1999, 1411, 437-455. [CrossRef]

77. Winkler, M.S.; Kluge, S.; Holzmann, M.; Moritz, E.; Robbe, L.; Bauer, A.; Zahrte, C.; Priefler, M.; Schwedhelm, E.; Böger, R.H.; et al. Markers of Nitric Oxide Are Associated with Sepsis Severity: An Observational Study. Crit. Care 2017, 21, 189. [CrossRef] [PubMed]

78. Ryter, S.W.; Choi, A.M.K. Targeting Heme Oxygenase-1 and Carbon Monoxide for Therapeutic Modulation of Inflammation. Transl. Res. 2016, 167, 7-34. [CrossRef]

79. Nielsen, V.G.; Pretorius, E. Carbon Monoxide: Anticoagulant or Procoagulant? Thromb. Res. 2014, 133, 315-321. [CrossRef]

80. Lagan, A.L.; Melley, D.D.; Evans, T.W.; Quinlan, G.J. Pathogenesis of the Systemic Inflammatory Syndrome and Acute Lung Injury: Role of Iron Mobilization and Decompartmentalization. Am. J. Physiol.—Lung Cell. Mol. Physiol. 2008, 294, L161-L174. [CrossRef]

81. Melley, D.D.; Finney, S.J.; Elia, A.; Lagan, A.L.; Quinlan, G.J.; Evans, T.W. Arterial Carboxyhemoglobin Level and Outcome in Critically Ill Patients. Crit. Care Med. 2007, 35, 1882-1887. [CrossRef] [PubMed]

82. Gutteridge, J.M.C.; Mumby, S.; Quinlan, G.J.; Chung, K.F.; Evans, T.W. Pro-Oxidant Iron Is Present in Human Pulmonary Epithelial Lining Fluid: Implications for Oxidative Stress in the Lung. Biochem. Biophys. Res. Commun. 1996, 220, 1024-1027. [CrossRef] [PubMed]

83. Gutteridge, J.M.C.; Quinlan, G.J.; Evans, T.W. Transient Iron Overload with Bleomycin Detectable Iron in the Plasma of Patients with Adult Respiratory Distress Syndrome. Thorax 1994, 49, 707-710. [CrossRef] [PubMed]

84. Gutteridge, J.M.C.; Quinlan, G.J. Antioxidant Protection against Organic and Inorganic Oxygen Radicals by Normal Human Plasma: The Important Primary Role for Iron-Binding and Iron-Oxidising Proteins. Biochim. Biophys. Acta 1993, 1156, 144-150. [CrossRef]

85. Cognasse, F.; Nguyen, K.A.; Damien, P.; McNicol, A.; Pozzetto, B.; Hamzeh-Cognasse, H.; Garraud, O. The Inflammatory Role of Platelets via Their TLRs and Siglec Receptors. Front. Immunol. 2015, 6, 83. [CrossRef]

86. Cooper, D.; Stokes, K.Y.; Tailor, A.; Granger, D.N. Oxidative Stress Promotes Blood Cell-Endothelial Cell Interactions in the Microcirculation. Cardiovasc. Toxicol. 2002, 2, 165-180. [CrossRef]

87. Joffre, J.; Hellman, J. Oxidative Stress and Endothelial Dysfunction in Sepsis and Acute Inflammation. Antioxid. Redox Signal. 2021, 35, 1291-1307. [CrossRef]

88. Krötz, F.; Sohn, H.Y.; Pohl, U. Reactive Oxygen Species: Players in the Platelet Game. Arterioscler. Thromb. Vasc. Biol. 2004, 24, 1988-1996. [CrossRef]

89. Tyml, K. Critical Role for Oxidative Stress, Platelets, and Coagulation in Capillary Blood Flow Impairment in Sepsis. Microcirculation 2011, 18, 152-162. [CrossRef]

90. Dworakowski, R.; Alom-Ruiz, S.P.; Shah, A.M. NADPH Oxidase-Derived Reactive Oxygen Species in the Regulation of Endothelial Phenotype. Pharmacol. Rep. 2008, 60, 21-28. [PubMed]

91. Koju, N.; Taleb, A.; Zhou, J.; Lv, G.; Yang, J.; Cao, X.; Lei, H.; Ding, Q. Pharmacological Strategies to Lower Crosstalk between Nicotinamide Adenine Dinucleotide Phosphate (NADPH) Oxidase and Mitochondria. Biomed. Pharmacother. 2019, 111, 1478-1498. [CrossRef]

92. Magnani, F.; Nenci, S.; Fananas, E.M.; Ceccon, M.; Romero, E.; Fraaije, M.W.; Mattevi, A. Crystal Structures and Atomic Model of NADPH Oxidase. Proc. Natl. Acad. Sci. USA 2017, 114, 6764-6769. [CrossRef]

93. de Carvalho, D.D.; Sadok, A.; Bourgarel-Rey, V.; Gattacceca, F.; Penel, C.; Lehmann, M.; Kovacic, H. Nox1 Downstream of 12-Lipoxygenase Controls Cell Proliferation but Not Cell Spreading of Colon Cancer Cells. Int. J. Cancer 2008, 122, $1757-1764$. [CrossRef] [PubMed]

94. Shin, S.W.; Seo, C.Y.; Han, H.; Han, J.Y.; Jeong, J.S.; Kwak, J.Y.; Park, J.I. 15d-PGJ2 Induces Apoptosis by Reactive Oxygen Species-Mediated Inactivation of Akt in Leukemia and Colorectal Cancer Cells and Shows in Vivo Antitumor Activity. Clin. Cancer Res. 2009, 15, 5414-5425. [CrossRef] [PubMed]

95. Valko, M.; Leibfritz, D.; Moncol, J.; Cronin, M.T.D.; Mazur, M.; Telser, J. Free Radicals and Antioxidants in Normal Physiological Functions and Human Disease. Int. J. Biochem. Cell Biol. 2007, 39, 44-84. [CrossRef] [PubMed]

96. Winterbourn, C.C. Toxicity of Iron and Hydrogen Peroxide: The Fenton Reaction. Toxicol. Lett. 1995, 82-83, 969-974. [CrossRef]

97. Zhao, R.Z.; Jiang, S.; Zhang, L.; Yu, Z.-B. Mitochondrial Electron Transport Chain, ROS Generation and Uncoupling (Review). Int. J. Mol. Med. 2019, 44, 3-15. [CrossRef]

98. Cho, K.J.; Seo, J.M.; Kim, J.H. Bioactive Lipoxygenase Metabolites Stimulation of NADPH Oxidases and Reactive Oxygen Species. Mol. Cells 2011, 32, 1-5. [CrossRef]

99. Yun, M.R.; Park, H.M.; Seo, K.W.; Lee, S.J.; Im, D.S.; Kim, C.D. 5-Lipoxygenase Plays an Essential Role in 4-HNE-Enhanced ROS Production in Murine Macrophages via Activation of NADPH Oxidase. Free Radic. Res. 2010, 44, 742-750. [CrossRef]

100. Battelli, M.G.; Polito, L.; Bortolotti, M.; Bolognesi, A. Xanthine Oxidoreductase-Derived Reactive Species: Physiological and Pathological Effects. Oxidative Med. Cell. Longev. 2016, 2016, 3527579. [CrossRef]

101. Marcondes, S.; Cardoso, M.H.M.; Morganti, R.P.; Thomazzi, S.M.; Lilla, S.; Murad, F.; de Nucci, G.; Antunes, E. Cyclic GMPIndependent Mechanisms Contribute to the Inhibition of Platelet Adhesion by Nitric Oxide Donor: A Role for-Actinin Nitration. Proc. Natl. Acad. Sci. USA 2006, 103, 3434-3439. [CrossRef] 
102. Nieuwdorp, M.; Meuwese, M.C.; Mooij, H.L.; van Lieshout, M.H.P.; Hayden, A.; Levi, M.; Meijers, J.C.M.; Ince, C.; Kastelein, J.J.P.; Vink, H.; et al. Tumor Necrosis Factor- $\alpha$ Inhibition Protects against Endotoxin-Induced Endothelial Glycocalyx Perturbation. Atherosclerosis 2009, 202, 296-303. [CrossRef] [PubMed]

103. Schmidt, E.P.; Yang, Y.; Janssen, W.J.; Gandjeva, A.; Perez, M.J.; Barthel, L.; Zemans, R.L.; Bowman, J.C.; Koyanagi, D.E.; Yunt, Z.X.; et al. The Pulmonary Endothelial Glycocalyx Regulates Neutrophil Adhesion and Lung Injury during Experimental Sepsis. Nat. Med. 2012, 18, 1217-1223. [CrossRef]

104. Fuchs, T.A.; Abed, U.; Goosmann, C.; Hurwitz, R.; Schulze, I.; Wahn, V.; Weinrauch, Y.; Brinkmann, V.; Zychlinsky, A. Novel Cell Death Program Leads to Neutrophil Extracellular Traps. J. Cell Biol. 2007, 176, 231-241. [CrossRef]

105. Manda-Handzlik, A.; Bystrzycka, W.; Cieloch, A.; Glodkowska-Mrowka, E.; Jankowska-Steifer, E.; Heropolitanska-Pliszka, E.; Skrobot, A.; Muchowicz, A.; Ciepiela, O.; Wachowska, M.; et al. Nitric Oxide and Peroxynitrite Trigger and Enhance Release of Neutrophil Extracellular Traps. Cell. Mol. Life Sci. 2020, 77, 3059-3075. [CrossRef] [PubMed]

106. Grundmann, S.; Fink, K.; Rabadzhieva, L.; Bourgeois, N.; Schwab, T.; Moser, M.; Bode, C.; Busch, H.J. Perturbation of the Endothelial Glycocalyx in Post Cardiac Arrest Syndrome. Resuscitation 2012, 83, 715-720. [CrossRef] [PubMed]

107. Ince, C.; Mayeux, P.R.; Nguyen, T.; Gomez, H.; Kellum, J.A.; Ospina-Tascón, G.A.; Hernandez, G.; Murray, P.; de Backer, D. The endothelium in sepsis. Shock 2016, 45, 259. [CrossRef]

108. Liu, Y.; Zhao, H.; Li, H.; Kalyanaraman, B.; Nicolosi, A.C.; Gutterman, D.D. Mitochondrial Sources of $\mathrm{H}_{2} \mathrm{O}_{2}$ Generation Play a Key Role in Flow-Mediated Dilation in Human Coronary Resistance Arteries. Circ. Res. 2003, 93, 573-580. [CrossRef]

109. Patil, N.K.; Parajuli, N.; Macmillan-Crow, L.A.; Mayeux, P.R. Inactivation of Renal Mitochondrial Respiratory Complexes and Manganese Superoxide Dismutase during Sepsis: Mitochondria-Targeted Antioxidant Mitigates Injury. Am. J. Physiol.—Ren. Physiol. 2014, 306, F734-F743. [CrossRef]

110. Cimmino, G.; Cirillo, P.; Ragni, M.; Conte, S.; Uccello, G.; Golino, P. Reactive Oxygen Species Induce a Procoagulant State in Endothelial Cells by Inhibiting Tissue Factor Pathway Inhibitor. J. Thromb. Thrombolysis 2015, 40, 186-192. [CrossRef]

111. Altenhöfer, S.; Witte, I.; Teiber, J.F.; Wilgenbus, P.; Pautz, A.; Li, H.; Daiber, A.; Witan, H.; Clement, A.M.; Förstermann, U.; et al. One Enzyme, Two Functions: PON2 Prevents Mitochondrial Superoxide Formation and Apoptosis Independent from Its Lactonase Activity. J. Biol. Chem. 2010, 285, 24398-24403. [CrossRef]

112. Ebert, J.; Wilgenbus, P.; Teiber, J.F.; Jurk, K.; Schwierczek, K.; Ohrmann, M.D.; Xia, N.; Li, H.; Spiecker, L.; Ruf, W.; et al. Paraoxonase-2 Regulates Coagulation Activation through Endothelial Tissue Factor. Blood 2018, 131, 2161-2172. [CrossRef]

113. Wu, F.; Schuster, D.P.; Tyml, K.; Wilson, J.X. Ascorbate Inhibits NADPH Oxidase Subunit P47phox Expression in Microvascular Endothelial Cells. Free Radic. Biol. Med. 2007, 42, 124-131. [CrossRef]

114. Muzaffar, S.; Jeremy, J.Y.; Angelini, G.D.; Stuart-Smith, K.; Shukla, N. Role of the Endothelium and Nitric Oxide Synthases in Modulating Superoxide Formation Induced by Endotoxin and Cytokines in Porcine Pulmonary Arteries. Thorax 2003, 58, 598-604. [CrossRef]

115. Cerwinka, W.H.; Cooper, D.; Krieglstein, C.F.; Ross, C.R.; McCord, J.M.; Granger, D.N. Superoxide Mediates Endotoxin-Induced Platelet-Endothelial Cell Adhesion in Intestinal Venules. Am. J. Physiol.—Heart Circ. Physiol. 2003, 284, H535-H541. [CrossRef] [PubMed]

116. Iba, T.; Levy, J.H. Derangement of the Endothelial Glycocalyx in Sepsis. J. Thromb. Haemost. 2019, 17, 283-294. [CrossRef]

117. Cheung, P.Y.; Salas, E.; Schulz, R.; Radomski, M.W. Nitric Oxide and Platelet Function: Implications for Neonatology. Semin. Perinatol. 1997, 21, 409-417. [CrossRef]

118. Ulloa, L.; Cai, B.; Deitch, E.A. Novel Insights for Systemic Inflammation in Sepsis and Hemorrhage. Mediat. Inflamm. 2010, 2010, 642462.

119. Wang, L.; Taneja, R.; Razavi, H.M.; Law, C.; Gillis, C.; Mehta, S. Specific Role of Neutrophil Inducible Nitric Oxide Synthase in Murine Sepsis-Induced Lung Injury in Vivo. Shock 2012, 37, 539-547. [CrossRef] [PubMed]

120. Farias Benjamim, C.; Santana Silva, J.; Bruno Fortes, Z.; Aparecida Oliveira, M.; Henrique Ferreira, S.; Queiroz Cunha, F. Inhibition of Leukocyte Rolling by Nitric Oxide during Sepsis Leads to Reduced Migration of Active Microbicidal Neutrophils. Infect. Immun. 2002, 70, 3602-3610. [CrossRef]

121. Iba, T.; Levy, J.H. Sepsis-Induced Coagulopathy and Disseminated Intravascular Coagulation. Anesthesiology 2020, 1, 1238-1245. [CrossRef]

122. Lopes-Pires, M.E.; Clarke, S.R.; Marcondes, S.; Gibbins, J.M. Lipopolysaccharide Potentiates Platelet Responses via Toll-like Receptor 4-Stimulated Akt-Erk-PLA2 Signalling. PLoS ONE 2017, 12, e0186981. [CrossRef]

123. Masselli, E.; Pozzi, G.; Vaccarezza, M.; Mirandola, P.; Galli, D.; Vitale, M.; Carubbi, C.; Gobbi, G. ROS in Platelet Biology: Functional Aspects and Methodological Insights. Int. J. Mol. Sci. 2020, 21, 4866. [CrossRef]

124. Lopes-Pires, M.E.; Casarin, A.L.; Pereira-Cunha, F.G.; Lorand-Metze, I.; Antunes, E.; Marcondes, S. Lipopolysaccharide Treatment Reduces Rat Platelet Aggregation Independent of Intracellular Reactive-Oxygen Species Generation. Platelets 2012, 23, 195-201. [CrossRef]

125. Dewitte, A.; Lepreux, S.; Villeneuve, J.; Rigothier, C.; Combe, C.; Ouattara, A.; Ripoche, J. Blood Platelets and Sepsis Pathophysiology: A New Therapeutic Prospect in Critical Ill Patients? Ann. Intensive Care 2017, 7, 115. [CrossRef]

126. Zhang, G.; Zhang, P.; Liu, H.; Liu, X.; Xie, S.; Wang, X.; Wu, Y.; Chang, J.; Ma, L. Assessment of Th17/Treg Cells and Th Cytokines in an Improved Immune Thrombocytopenia Mouse Model. Hematology 2017, 22, 493-500. [CrossRef] 
127. Nguyen, G.T.; Green, E.R.; Mecsas, J. Neutrophils to the ROScue: Mechanisms of NADPH Oxidase Activation and Bacterial Resistance. Front. Cell. Infect. Microbiol. 2017, 7, 373. [CrossRef] [PubMed]

128. Fuentes, E.; Gibbins, J.M.; Holbrook, L.M.; Palomo, I. NADPH Oxidase 2 (NOX2): A Key Target of Oxidative Stress-Mediated Platelet Activation and Thrombosis. Trends Cardiovasc. Med. 2018, 28, 429-434. [CrossRef] [PubMed]

129. Seno, T.; Inoue, N.; Gao, D.; Okuda, M.; Sumi, Y.; Matsui, K.; Yamada, S.; Hirata, K.I.; Kawashima, S.; Tawa, R.; et al. Involvement of NADH/NADPH Oxidase in Human Platelet ROS Production. Thromb. Res. 2001, 103, 399-409. [CrossRef]

130. Sonkar, V.K.; Kumar, R.; Jensen, M.; Wagner, B.A.; Sharathkumar, A.A.; Miller, F.J.; Fasano, M.B.; Lentz, S.R.; Buettner, G.R.; Dayal, S. Nox2 NADPH Oxidase Is Dispensable for Platelet Activation or Arterial Thrombosis in Mice. Blood Adv. 2019, 3, $1272-1284$. [CrossRef]

131. Vara, D.; Tarafdar, A.; Celikag, M.; Patinha, D.; Gulacsy, C.E.; Hounslea, E.; Warren, Z.; Ferreira, B.; Koeners, M.P.; Caggiano, L.; et al. NADPH Oxidase 1 Is a Novel Pharmacological Target for the Development of an Antiplatelet Drug without Bleeding Side Effects. FASEB J. 2020, 34, 13959-13977. [CrossRef]

132. Lopes Pires, M.E.; Antunes Naime, A.C.; Oliveira, J.G.F.; Anhe, G.F.; Garraud, O.; Cognasse, F.; Antunes, E.; Marcondes, S. Signalling Pathways Involved in P47 Phox -Dependent Reactive Oxygen Species in Platelets of Endotoxemic Rats. Basic Clin. Pharmacol. Toxicol. 2019, 124, 394-403. [CrossRef]

133. Clark, S.R.; Ma, A.C.; Tavener, S.A.; McDonald, B.; Goodarzi, Z.; Kelly, M.M.; Patel, K.D.; Chakrabarti, S.; McAvoy, E.; Sinclair, G.D.; et al. Platelet TLR4 Activates Neutrophil Extracellular Traps to Ensnare Bacteria in Septic Blood. Nat. Med. 2007, 13, 463-469. [CrossRef] [PubMed]

134. Parker, H.; Dragunow, M.; Hampton, M.B.; Kettle, A.J.; Winterbourn, C.C. Requirements for NADPH Oxidase and Myeloperoxidase in Neutrophil Extracellular Trap Formation Differ Depending on the Stimulus. J. Leukoc. Biol. 2012, 92, 841-849. [CrossRef] [PubMed]

135. Camicia, G.; Pozner, R.; de Larrañaga, G. Neutrophil Extracellular Traps in Sepsis. Shock 2014, 42, 286-294. [CrossRef] [PubMed]

136. Puskarich, M.A.; Kline, J.A.; Watts, J.A.; Shirey, K.; Hosler, J.; Jones, A.E. Early Alterations in Platelet Mitochondrial Function Are Associated with Survival and Organ Failure in Patients with Septic Shock. J. Crit. Care 2016, 31, 63-67. [CrossRef]

137. Sjövall, F.; Morota, S.; Hansson, M.J.; Friberg, H.; Gnaiger, E.; Elmér, E. Temporal Increase of Platelet Mitochondrial Respiration Is Negatively Associated with Clinical Outcome in Patients with Sepsis. Crit. Care 2010, 14, R214. [CrossRef]

138. Mantzarlis, K.; Tsolaki, V.; Zakynthinos, E. Role of Oxidative Stress and Mitochondrial Dysfunction in Sepsis and Potential Therapies. Oxidative Med. Cell. Longev. 2017, 2017, 5985209. [CrossRef] [PubMed]

139. Matsumoto, S.; Koga, H.; Kusaka, J.; Hagiwara, S. Effects of the Antioxidant-Enriched Concentrated Liquid Diet ANOM on Oxidative Stress and Multiple Organ Injury in Patients with Septic Shock: A Pilot Study. J. Anesth. Clin. Res. 2011, 2, 8. [CrossRef]

140. Shen, K.-P.; Lo, Y.-C.; Yang, R.-C.; Liu, H.-W.; Chen, I.-J.; Wu, B.-N. Antioxidant Eugenosedin-A Protects against Lipopolysaccharide-Induced Hypotension, Hyperglycaemia and Cytokine Immunoreactivity in Rats and Mice. J. Pharm. Pharmacol. 2010, 57, 117-125. [CrossRef]

141. Pleiner, J.; Mittermayer, F.; Schaller, G.; Marsik, C.; Macallister, R.J.; Wolzt, M. Inflammation-Induced Vasoconstrictor Hyporeactivity Is Caused by Oxidative Stress. J. Am. Coll. Cardiol. 2003, 42, 1656-1662. [CrossRef]

142. Sakr, Y.; Vincent, J.-L.; Schuerholz, T.; Filipescu, D.; Romain, A.; Hjelmqvist, H.; Reinhart, K. Early- versus Late-Onset Shock in European Intensive Care Units. Shock 2007, 28, 636-643. [CrossRef]

143. Forceville, X.; Vitoux, D.; Gauzit, R.; Combes, A.; Lahilaire, P.; Chappuis, P. Selenium, Systemic Immune Response Syndrome, Sepsis, and Outcome in Critically Ill Patients. Crit. Care Med. 1998, 26, 1536-1544. [CrossRef] [PubMed]

144. Angstwurm, M.W.A.; Engelmann, L.; Zimmermann, T.; Lehmann, C.; Spes, C.H.; Abel, P.; Strauß, R.; Meier-Hellmann, A.; Insel, R.; Radke, J.; et al. Selenium in Intensive Care (SIC): Results of a Prospective Randomized, Placebo-Controlled, Multiple-Center Study in Patients with Severe Systemic Inflammatory Response Syndrome, Sepsis, and Septic Shock. Crit. Care Med. 2007, 35, 118-126. [CrossRef]

145. Manzanares, W.; Lemieux, M.; Elke, G.; Langlois, P.L.; Bloos, F.; Heyland, D.K. High-Dose Intravenous Selenium Does Not Improve Clinical Outcomes in the Critically Ill: A Systematic Review and Meta-Analysis. Crit. Care 2016, 20, 356. [CrossRef] [PubMed]

146. Pei, Y.; Liu, H.; Yang, Y.; Yang, Y.; Jiao, Y.; Tay, F.R.; Chen, J. Biological Activities and Potential Oral Applications of NAcetylcysteine: Progress and Prospects. Oxidative Med. Cell. Longev. 2018, 2018, 2835787. [CrossRef]

147. de Mello, R.O.; Lunardelli, A.; Caberlon, E.; de Moraes, C.M.B.; Christ Vianna Santos, R.; da Costa, V.L.; da Silva, G.V.; da Silva Scherer, P.; Buaes, L.E.C.; da Silva Melo, D.A.; et al. Effect of N-Acetylcysteine and Fructose-1,6-Bisphosphate in the Treatment of Experimental Sepsis. Inflammation 2011, 34, 539-550. [CrossRef]

148. Ritter, C.; Reinke, A.; Andrades, M.; Martins, M.R.; Rocha, J.; Menna-Barreto, S.; Quevedo, J.; Moreira, J.C.F.; Dal-Pizzol, F. Protective Effect of N-Acetylcysteine and Deferoxamine on Carbon Tetrachloride-Induced Acute Hepatic Failure in Rats. Crit. Care Med. 2004, 32, 2079-2083. [CrossRef] [PubMed]

149. Villa, P.; Saccani, A.; Sica, A.; Ghezzi, P. Glutathione Protects Mice from Lethal Sepsis by Limiting Inflammation and Potentiating Host Defense. J. Infect. Dis. 2002, 185, 1115-1120. [CrossRef]

150. Schmidt, W.; Walther, A.; Gebhard, M.M.; Martin, E.; Schmidt, H. Influence of N-Acetylcysteine Treatment on Endotoxin-Induced Microcirculatory Disturbances. Intensive Care Med. 1998, 24, 967-972. [CrossRef] 
151. Chertoff, J. N-Acetylcysteine's Role in Sepsis and Potential Benefit in Patients With Microcirculatory Derangements. J. Intensive Care Med. 2018, 33, 87-96. [CrossRef]

152. Ortolani, O.; Conti, A.; de Gaudio, A.R.; Moraldi, E.; Cantini, Q.; Novelli, G. The Effect of Glutathione and N-Acetylcysteine on Lipoperoxidative Damage in Patients with Early Septic Shock. Am. J. Respir. Crit. Care Med. 2000, 161, 1907-1911. [CrossRef] [PubMed]

153. Spies, C.D.; Reinhart, K.; Witt, I.; Meier-Hellmann, A.; Hannemann, L.; Bredle, D.L.; Schaffartzik, W. Influence of N-Acetylcysteine on Indirect Indicators of Tissue Oxygenation in Septic Shock Patients: Results from a Prospective, Randomized, Double-Blind Study. Crit. Care Med. 1994, 22, 1738-1746. [CrossRef] [PubMed]

154. Bastin, A.J.; Davies, N.; Lim, E.; Quinlan, G.J.; Griffiths, M.J. Systemic Inflammation and Oxidative Stress Post-Lung Resection: Effect of Pretreatment with N-Acetylcysteine. Respirology 2016, 21, 180-187. [CrossRef] [PubMed]

155. Heller, A.R.; Groth, G.; Heller, S.C.; Breitkreutz, R.; Nebe, T.; Quintel, M.; Koch, T. N-Acetylcysteine Reduces Respiratory Burst but Augments Neutrophil Phagocytosis in Intensive Care Unit Patients. Crit. Care Med. 2001, 29, 272-276. [CrossRef]

156. Spapen, H.D. Effects of N-Acetylcysteine on Microalbuminuria and Organ Failure in Acute Severe Sepsis. CHEST J. 2005, 127, 1413. [CrossRef]

157. Rodriguez-Cuenca, S.; Cochemé, H.M.; Logan, A.; Abakumova, I.; Prime, T.A.; Rose, C.; Vidal-Puig, A.; Smith, A.C.; Rubinsztein, D.C.; Fearnley, I.M.; et al. Consequences of Long-Term Oral Administration of the Mitochondria-Targeted Antioxidant MitoQ to Wild-Type Mice. Free Radic. Biol. Med. 2010, 48, 161-172. [CrossRef]

158. Lowes, D.A.; Webster, N.R.; Murphy, M.P.; Galley, H.F. Antioxidants That Protect Mitochondria Reduce Interleukin-6 and Oxidative Stress, Improve Mitochondrial Function, and Reduce Biochemical Markers of Organ Dysfunction in a Rat Model of Acute Sepsis. Br. J. Anaesth. 2013, 110, 472-480. [CrossRef]

159. Okado-Matsumoto, A.; Fridovich, I. Subcellular Distribution of Superoxide Dismutases (SOD) in Rat Liver. J. Biol. Chem. 2001, 276, 38388-38393. [CrossRef]

160. McCord, J.M.; Fridovich, I. Superoxide Dismutase. An Enzymic Function for Erythrocuprein (Hemocuprein). J. Biol. Chem. 1969, 244, 6049-6055. [CrossRef]

161. Macarthur, H.; Couri, D.M.; Wilken, G.H.; Westfall, T.C.; Lechner, A.J.; Matuschak, G.M.; Chen, Z.; Salvemini, D. Modulation of Serum Cytokine Levels by a Novel Superoxide Dismutase Mimetic, M40401, in an Escherichia Coli Model of Septic Shock: Correlation with Preserved Circulating Catecholamines. Crit. Care Med. 2003, 31, 237-245. [CrossRef] [PubMed]

162. Privalle, C.; Talarico, T.; Keng, T.; DeAngelo, J. Pyridoxalated Hemoglobin Polyoxyethylene: A Nitric Oxide Scavenger with Antioxidant Activity for the Treatment of Nitric Oxide-Induced Shock. Free Radic. Biol. Med. 2000, 28, 1507-1517. [CrossRef]

163. Bone, H.G.; Schenarts, P.J.; Fischer, S.R.; McGuire, R.; Traber, L.D.; Traber, D.L. Pyridoxalated Hemoglobin Polyoxyethylene Conjugate Reverses Hyperdynamic Circulation in Septic Sheep. J. Appl. Physiol. 1998, 84, 1991-1999. [CrossRef] [PubMed]

164. Bone, H.G.; Schenarts, P.J.; Booke, M.; McGuire, R.; Harper, D.; Traber, L.D.; Traber, D.L. Oxalated Pyridoxalated Hemoglobin Polyoxyethylene Conjugate Normalizes the Hyperdynamic Circulation in Septic Sheep. Crit. Care Med. 1997, 25, 1010-1018. [CrossRef] [PubMed]

165. Grover, R.; Zaccardelli, D.; Colice, G.; Guntupalli, K.; Watson, D.; Vincent, J.L. An Open-Label Dose Escalation Study of the Nitric Oxide Synthase Inhibitor, N(G)-Methyl-L-Arginine Hydrochloride (546C88), in Patients with Septic Shock. Glaxo Wellcome International Septic Shock Study Group. Crit. Care Med. 1999, 27, 913-922. [CrossRef] [PubMed]

166. Vincent, J.-L.; Privalle, C.T.; Singer, M.; Lorente, J.A.; Boehm, E.; Meier-Hellmann, A.; Darius, H.; Ferrer, R.; Sirvent, J.-M.; Marx, G.; et al. Multicenter, Randomized, Placebo-Controlled Phase III Study of Pyridoxalated Hemoglobin Polyoxyethylene in Distributive Shock (PHOENIX). Crit. Care Med. 2015, 43, 57-64. [CrossRef] [PubMed]

167. Loren, P.; Sánchez, R.; Arias, M.-E.; Felmer, R.; Risopatrón, J.; Cheuquemán, C. Melatonin Scavenger Properties against Oxidative and Nitrosative Stress: Impact on Gamete Handling and In Vitro Embryo Production in Humans and Other Mammals. Int. J. Mol. Sci. 2017, 18, 1119. [CrossRef] [PubMed]

168. Sener, G.; Toklu, H.; Kapucu, C.; Ercan, F.; Erkanli, G.; Kaçmaz, A.; Tilki, M.; Yeğen, B.C. Melatonin Protects against Oxidative Organ Injury in a Rat Model of Sepsis. Surg. Today 2005, 35, 52-59. [CrossRef]

169. Alamili, M.; Bendtzen, K.; Lykkesfeldt, J.; Rosenberg, J.; Gögenur, I. Melatonin Suppresses Markers of Inflammation and Oxidative Damage in a Human Daytime Endotoxemia Model. J. Crit. Care 2014, 29, 184.e9-184.e13. [CrossRef] 